\title{
Sources and Reliability of Property Market Information for Property Valuation Practice in Ghana
}

\begin{tabular}{|r|l|}
\hline Journal: & Property Management \\
\hline Manuscript ID & PM-05-2016-0019.R1 \\
\hline Manuscript Type: & Research Paper \\
\hline Keywords: & Data, Ghana, property market, sources, valuation \\
\hline & \\
\end{tabular}

SCHOLARONE ${ }^{\text {m }}$

Manuscripts 


\section{List of Figures}

Figure 1: Guidelines for Effective Property/Market Data for Valuation Practice

\section{Property Market Data Collection} Planning

- A need to plan property market data collection exercise

- Determine activities involved in the property market data collection

- Determine the possible challenges to the proposed data collection

- Devise strategy(ies) for the data collection

- Determine the people to undertake the data collection

- Ensure they have the suitable training, skills and capacity to under effective

- Determine the probable cost for the data oollection a explore ways to mitigate it

\section{Purpose/Need Analysis for} Proper ty Mar ket Data

- Gear establistment of valuation assigrment \& purpose

- Determine the possible methods to undertake the valuation assignment a address the purpose of valuation

- Determine the most reliable method to undertake the valuation assignment $\mathrm{A}$ its purpose

- Determine the property market data needed to address the valuation assigrment

- Determine the requirements for the property market data needed to exeoute the valuation assigment $a$ address its purpose

\section{Possible Property Market Data}

\section{Sources}

- Identify all the possible property market data souroes induding own database

- Evaluate the possible property market data souroes

- Determine the property market data sources that can provide the data needs and requirements to execute the valuation assignment $\mathrm{a}$ its purpose

- Evaluate the relibility of each of the determined property market data sources in terms of supply and qua ity of data

- Determine the reliable data sources 
Figure 2

\begin{tabular}{|c|c|c|c|c|c|}
\hline \multirow{2}{*}{ 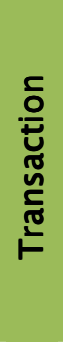 } & $\begin{array}{c}\text { Date } \\
{[\mathrm{DD} / \mathrm{MM} / \mathrm{YY}]}\end{array}$ & $\begin{array}{c}\text { Nature } \\
\text { [Eg } \\
\text { Sale/Rental] }\end{array}$ & 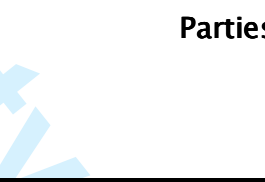 & $\begin{array}{l}\text { Consideration } \\
\text { [Eg Sale } \\
\text { price] }\end{array}$ & $\begin{array}{c}\text { Transaction } \\
\text { Conditions } \\
\text { [Eg Arm's } \\
\text { length] }\end{array}$ \\
\hline & & & $\begin{array}{l}\text { Eg. Seller/Landlord } \\
\text { Eg. } \\
\text { Purchaser/Tenant }\end{array}$ & & \\
\hline
\end{tabular}

\begin{tabular}{|c|c|c|c|c|c|}
\hline \multirow{8}{*}{ 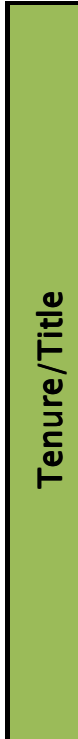 } & Type of Tenure [Ticl & Terms of Tenure & \multicolumn{2}{|c|}{ Registration Status } & Encumbrances \\
\hline & Allodial & Term & $\begin{array}{c}\text { Registration } \\
\text { Date }\end{array}$ & {$[\mathrm{DD} / \mathrm{MM} / \mathrm{YY}]$} & \\
\hline & $\begin{array}{c}\text { Freehold/Customary } \\
\text { Freehold }\end{array}$ & $\begin{array}{c}\text { Commencement } \\
\text { date }\end{array}$ & & & \\
\hline & Leasehold & Expiration date & & & \\
\hline & & $\begin{array}{c}\text { Option to renew } \\
\text { [For lesser } \\
\text { tenures] }\end{array}$ & $\begin{array}{l}\text { Registration } \\
\text { Number }\end{array}$ & & \\
\hline & Sublease & $\begin{array}{c}\text { Unexpired term } \\
\text { [For lesser } \\
\text { tenures] }\end{array}$ & & & \\
\hline & License & Ground & & & \\
\hline & Other [Specify] & $\begin{array}{l}\text { rent/contract } \\
\text { rent[For lesser } \\
\text { tenures] }\end{array}$ & & & \\
\hline
\end{tabular}

\begin{tabular}{|c|c|c|c|c|c|}
\hline $\begin{array}{l}\text { 릉 } \\
\text { 음 } \\
\text { ¿ }\end{array}$ & Property Type & $\begin{array}{l}\text { Description } \\
\text { [Eg detached, } \\
\text { semi- } \\
\text { detached, } \\
\text { bungalow - } \\
\text { with }\end{array}$ & Stage of Development & Total Floor Area & $\begin{array}{l}\text { Land } \\
\text { Size }\end{array}$ \\
\hline
\end{tabular}

\section{Property Market Data Collection Template}

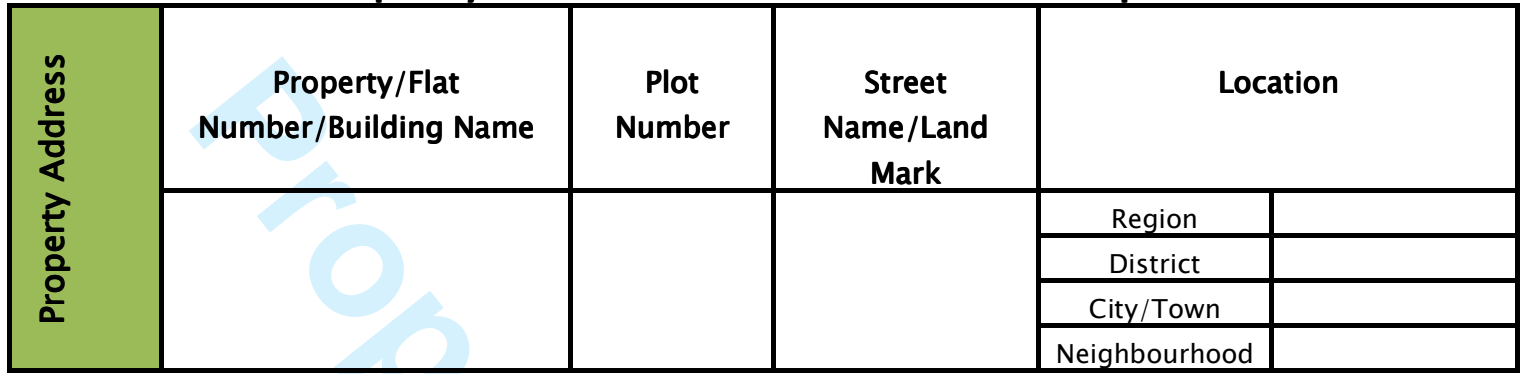




\begin{tabular}{|c|c|c|c|}
\hline & outbuilding] & & \\
\hline Residential & & $\begin{array}{c}\text { Main } \\
\text { building }\end{array}$ & Main building \\
\hline $\begin{array}{c}\text { Commercial } \\
\text { [ eg retail } \\
\text { shop/office] }\end{array}$ & & \multirow{6}{*}{ Outbuilding } & \multirow{6}{*}{ Outbuilding } \\
\hline $\begin{array}{c}\text { Mixed land } \\
\text { utilisation } \\
\end{array}$ & & & \\
\hline Industrial & & & \\
\hline Educational & & & \\
\hline Recreation & & & \\
\hline $\begin{array}{c}\text { Other } \\
\text { [Specify] }\end{array}$ & & & \\
\hline
\end{tabular}

\begin{tabular}{|c|c|c|c|c|c|c|}
\hline \multirow{14}{*}{ 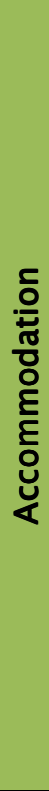 } & \multicolumn{3}{|c|}{ Main building } & \multicolumn{3}{|c|}{ Outbuilding } \\
\hline & Number of rooms & & & $\begin{array}{c}\text { Number of } \\
\text { rooms }\end{array}$ & & \\
\hline & Rooms & Description & Size & & & \\
\hline & Eg. Bedroom & En-suite & $18.6 \mathrm{~m}$ & Rooms & Description & Size \\
\hline & Eg. Living room & & & & & \\
\hline & & & & & & \\
\hline & & & & & & \\
\hline & Other Spaces & Description & Size & Other Spaces & Description & Size \\
\hline & Eg. Porch & & 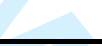 & & & \\
\hline & Eg. Kitchen & & & & & \\
\hline & & & & & & \\
\hline & & & & & & \\
\hline & $\begin{array}{c}\text { Orientation of } \\
\text { rooms }\end{array}$ & & & $\begin{array}{c}\text { Orientation of } \\
\text { rooms }\end{array}$ & & \\
\hline & $\begin{array}{c}\text { External Works } \\
\text { Eg. Compound, } \\
\text { carport }\end{array}$ & & & & & \\
\hline
\end{tabular}

\begin{tabular}{|c|c|c|c|}
\hline \multirow{10}{*}{ 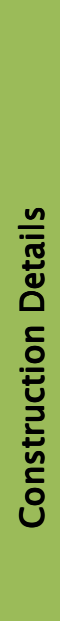 } & & Main building & Outbuilding \\
\hline & Foundation & & \\
\hline & Floors & & \\
\hline & Walls & & \\
\hline & Doors & & \\
\hline & Windows & & - \\
\hline & Ceiling & & \\
\hline & Roof & & \\
\hline & Fixtures \& Fittings & & \\
\hline & External Works & & \\
\hline
\end{tabular}




\begin{tabular}{|c|c|c|c|c|}
\hline \multirow{6}{*}{ 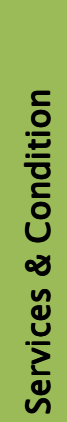 } & & Main building & Outbuilding & External Works \\
\hline & Electricity & & & \\
\hline & $\begin{array}{c}\text { Pipe borne } \\
\text { Water/Water }\end{array}$ & & & \\
\hline & Telephone & & & \\
\hline & Age & & & \\
\hline & General Condition & & & \\
\hline
\end{tabular}

\begin{tabular}{|c|c|c|}
\hline & Approved Planning Scheme & \\
\hline & Zoning Status & \\
\hline$\infty$ ळ & Building Permit & \\
\hline סี $\frac{n}{E}$ & Fire Safety Clearance & \\
\hline 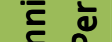 & EPA Clearance & \\
\hline & $\begin{array}{c}\text { Traffic Impact Assessment } \\
\text { Clearance }\end{array}$ & \\
\hline
\end{tabular}

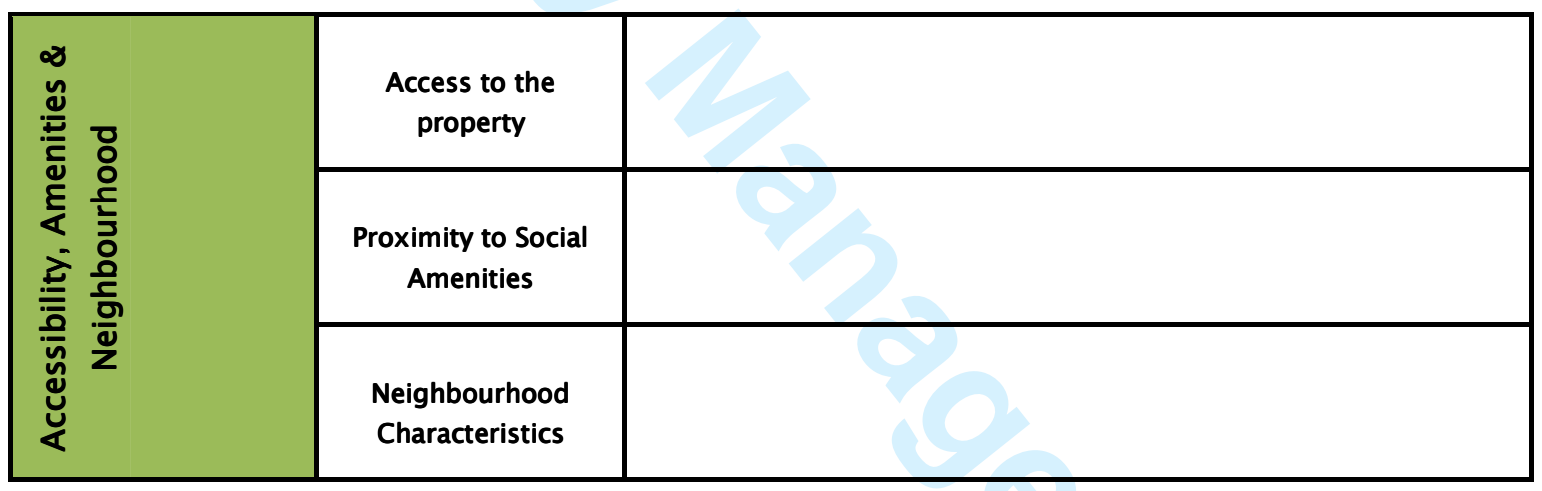

\begin{tabular}{|c|c|c|}
\hline Data Source & Compiled By & $\begin{array}{c}\text { Date } \\
{[\mathrm{DD} / \mathrm{MM} / \mathrm{YY}]}\end{array}$ \\
\hline & & \\
\hline
\end{tabular}




\begin{abstract}
Purpose: Adequate reliable property market data is critical to the production of professional and ethical valuations as well as better real estate transaction decision-making. However, the availability of reliable property market information represents a major barrier to improving valuation practices in Ghana and it is regarded as a key challenge. This study investigates the sources and reliability of property market information for valuation practice in Ghana. The aim is to provide input into initiatives to address the availability of reliable property market data challenges.
\end{abstract}

Design/Methodology/Approach - A mixed methods research approach is used. The study, thus, relies on a combination of a systematic identification and review of literature, a stakeholder workshop and a questionnaire survey of real estate valuers in Accra, Ghana's capital city to obtain requisite data to address the aim.

Findings - The study identifies seven (7)_property market data sources used by valuers to obtain market data for valuation practice. These are: valuers own database; public institutions; professional colleagues; property owners; estate developers; estate agents; and the media. However, access to property market information for valuations is a challenge_although valuers would like to use reliable market data for their valuations. This is due to incomplete and scattered nature of data often borne out of administrative lapses; nondisclosure of details of property transactions due to confidentiality arrangements and the quest to evade taxes; data integrity concerns; and lack of requisite training and experience especially for estate agents to collect and manage market data. Although professional colleagues is the most used market data source, valuers own databases, was regarded as the most reliable source compared to the media, which was considered as the least reliable source.

Research Implications - Findings from the study imply a need for the development of a systematic approach to property market data collection and management. This will require practitioners to demonstrate care, 
consciousness and a set of data collection skills suggesting a need for valuers and estate agents to undergo regular_relevant training to develop and enhance their knowledge, skills and capabilities. The establishment of a property market databank to help in the provision of reliable market data along with a suitable market data collection template to ensure effective and efficient data collection are considered essential steps.

Originality - The study makes a significant contribution to the_extant knowledge by providing empirical evidence on the frequency of use and the reliability of the various sources of market data. It also provides useful insights for regulators such as the Ghana Institution of Surveyors (GhIS), the RICS and other stakeholders_such as the Commonwealth Association of Surveying and Land Economy (CASLE) and the Government to improve the provision of reliable property market information towards developing valuation practice not only in Chana, but across the Sub-Saharan Africa Region. Also, based on these findings, the study proposes a new property market data collection template and guidelines towards improving the collection of effective property market data. Upon refinement, these could aid valuation practitioners to collect reliable property market data to improve valuation practice.

Keywords:_Data, Ghana, property market, sources, valuation

\section{Introduction}

The impact of adequate and reliable property market information on the production of professional and ethical valuation for real estate transaction decision-making is very significant (Dunse et al., 1998; Ge and Harfield, 2006; Mends, 2006). Inadequate and unreliable market data has a high tendency to lead to the production of inaccurate valuations. This situation could affect the property market performance and investor confidence, derail investment and impact greatly on an economy_(Ge and Harfield, 2006). However, property market information is often difficult to come by. Consequently countries, in particular, those of the Western developed world over the years continue to develop institutions and create the enabling 
environment to improve access to reliable property market information. Conversely, inadequate access to reliable market information for improved property valuation practice in developing countries such as Ghana appears to be worsening. This is compounded by inefficient property market operations and the ineptitude of market participants as well as public sector lapses and inertia (Mends, 2006; Mahama and Antwi; PWC, 2012).

An essential pre-requisite for access to adequate and reliable property market information to improve valuation practice in Ghana, boost investor confidence and stimulate investment activities is a need for a conceptual and practical shift in the way market information is collected, managed, provided and accessed. However, a suitable and pragmatic prescription will, in part, require identification and understanding of existing market information sources and the reliability of the information produced by the sources. This could provide a background input into proposed prescriptions for a shift in existing practices. This study, therefore, seeks to investigate property market information sources for valuation practice in Ghana and analyse the reliability of the information they provide. The aim is to provide input for initiatives to address property market information for valuation practice challenges in the country. The remainder of the study is organised as follows. The next section discusses property market data sources and challenges in Ghana to set the context for the study. This is followed by an account of the approach and methodology employed for the study._Findings from the study and their discussions are thereafter provided before conclusions are drawn.

\section{Property Market Data Sources and Challenges in Ghana}

Professional and ethical property valuations are vital to decision-making, and are in turn critical to the efficient operation of property markets and national economies (Aluko, 2004; Babawale and Ajayi, 2011). This decisionmaking relates to issues such as: sale, purchase and letting of properties; real estate investment and management;_compulsory purchase of land and properties; real estate taxation and insurance; real estate inheritance and settlement; asset sharing, allocation and re-allocation; and_government divestiture and privatisation programmes. Although several factors inform professional and ethical property valuations, availability of reliable and quality property market information is perceived as very significant (Peto, 
1997; Dunse et al., 1998; Gilbertson and Preston, 2005; Ge and Harfield, 2006).Indeed, Brown (1992) notes that valuations are a function of market information. Also, Ratcliff (1968) in Brown (1992) acknowledges that property valuation is not different from any other economic forecast and such a forecast is partly a function of adequacy of property market information and partly down to the skill and competence of the analyst.

\section{Indicators for Reliable and Quality Data.}

The central characteristics of reliability and quality are: dependability; stability; consistency; predictability and accuracy (Ge and Harfield, 2006). This means that for adequate, reliable and quality property market information, there must be a timely collection of property market data, and the data should be complete and accurate (Gudat, 2010). Also, the data collected should be up-dated at regular intervals._Ge and Harfield_(2006) further suggest that data should have some form of historical validity meaning that clearly defined explanations of changes in methodologies applied and measurement of variables should be available. This is to ensure consistency in interpretation of data sets over time. Dwelling on the criteria for assessing quality data, Ge and Harfield_(2006) additionally suggest property data should satisfy three other requirements. These are: the public availability of data; data conformity to internationally accepted standards or factors; and the comprehensiveness of data. Public availability of data relates to openness of data to the public, which could be accessed freely or at a fee. However, conformity to intentionally accepted standards or factors appears quite vague as it is unclear whether or not such internationally accepted standards have been developed (Gudat, 2010. Nevertheless, for valuation practice it is expected that reliable property market data will provide information such as: source of the data, the property type and size,_the date the transaction took place; location of the subject property; interest in the property; development status of the property; agreed consideration; and history of the transaction (Wyatt, 1997; Mends, 2006; Ashaolu and Olaniran, 
2016). This feeds into the comprehensiveness of data, which requires that all aspects of data are collected, up-dated and managed.

\section{Market Data Sources and Challenges}

Property market data for valuation purpose are obtained from several sources in Ghana. The literature identifies six main sources. These are: public and quasi-public institutions such as the Lands Commission, Architectural and Engineering Services Limited (AESL), Tema Development Corporation (TDC), State Housing Company Limited (SHC) and the Metropolitan, Municipal and District Assemblies (MMDAs); property owners; property valuation practitioners, professional property consultancy firms and lawyers who deal with property transactions (professional colleagues); practitioners own databases; real estate developers; and informal real estate agents (Mends, 2006; Mahama and Antwi, 2006). Notwithstanding these sources, availability of reliable and quality property market data for valuation practice is regarded as a huge challenge in Ghana (Mahama and Antwi, 2006) due to the various deficiencies in data obtainable from such sources.

As can be seen from the preceding discussions, an essential feature of a reliable and quality data is its completeness or comprehensiveness. However, market data obtained from public and quasi-public institutions are often incomplete and not well organised. Data obtained from these institutions often do not provide information such as agreed considerations and date of transactions, and they are not regularly updated_(Mends, 2006). Apart from administrative lapses, the problem with market data obtained from public and quasi-public institutions is attributed to the secrecy usually associated with property transactions (Gough and Yankson, 2000) and deliberate nondisclosure of information by parties to transactions for tax evasion purposes. Due to confidentiality arrangements, property owners and purchasers as well as real estate developers are often unwilling to disclose details of transactions. This makes access to market data for valuation purpose from these sources difficult. Further, Mends (2006) notes that valuation practitioners, professional property consultancy firms and some lawyers have built some form of databases, which they usually share with colleagues. However, the source of the data provided by these databases is often unknown and the integrity of the data is most of the time questionable. In fact, anecdotal evidence suggests that there are instances where same data are acquired from different sources, but with significant variations. These 
constraints, therefore, raise questions about the quality and reliability of market data supplied by this source.

Informal real estate agents' constitutes a major source of property market data for valuation practice in Ghana. However, they often lack the requisite training and experience to collect and manage quality data for valuation purpose (Mahama and Antwi, 2006; Obeng-Odoom, 2011). Excepting their primary interest of earning commissions, they hardly record transaction details, circumstances, property characteristics and the financial arrangements for transactions, which are critical to quality and reliable data.

The literature discussions so far demonstrate that access to reliable property market information for valuation practice in Ghana could be a challenge. The question, however, is: to what extent do practitioners experience these challenges with access and how do they perceive the quality and reliability of the data they use or choose not to use. These constitute the focus of the study and to examine them, the methodology for doing so is first outlined in the next section.

\section{Research Methodology}

The study initially identified and reviewed the focal literature to gain some background insights into the relevance of property market data to property valuation, sources of market data for valuation practice in Ghana and the challenges. The rationale was to identify the existing knowledge, and provide the study context. The literature review was followed by a one-day stakeholder consultation with practitioners - valuation and estate surveyors in Accra. The workshop was organised with the assistance and support of the ChIS, RICS and the Commonwealth Association of Surveying and Land Economy (CASLE). The workshop was organised in three phases. The first phase was devoted to presentations bordering on the research. The presentations focused on the research background, findings from the literature evaluation, and related issues such as market data challenges. The second phase was a break-out session where the participants were divided into five groups to discuss pre-formulated questions related to the research. The discussions were facilitated by a chairperson. Each of the groups also had a rapporteur who recorded the outcome of the discussions. The third phase was a plenary session where outcomes from the group discussions were reported and discussed. The aim was to engage with practitioners, gain 
additional insights and facilitate empirical data collection. Thus, the workshop helped to confirm the issues identified in the literature and also identified new issues which were not revealed such as property market data sources and possible fields of information for a suitable property market data collection template. It also helped to identify useful informants and uncover data sources, which were leveraged to obtain data to deliver the research.

Subsequently, a questionnaire survey of real estate valuers in Accra was undertaken. The survey was undertaken between July and September, 2015 with the assistance and support of the GhIS. The survey targeted professional members of the GhIS. The questionnaire was designed based on the insights gained from the literature review and the outcome from the stakeholder consultation workshop. Therefore, apart from background information of respondents, the questionnaire sought information on the extent of use of market data sources by practitioners, the reliability of the property market data sources for valuation practice in Ghana, the relevance of property market data collection template to effective market data collection in the country as well as the information (fields) that a suitable property market data collection template should contain. A Likert scale was used to assist in eliciting the information that was sought by the questionnaire. Thus, on a scale of 1-5 (where $1=$ do not use at all, $2=$ rarely, $3=$ quite often, $4=$ often and 5 very often), the respondents were asked to rate their extent of use of the main market data sources to obtain information to undertake their valuations. A similar arrangement was used to obtain the requisite information on the extent of reliability of data from the sources, the relevance of a proposed data collection template to effective data collection and the information that a suitable template should contain.

The questionnaires were self-administered to the respondents. A total of 110 questionnaires were administered. Due to lack of a reliable sample frame, selection of the respondents was based on purposive and snowball sampling methods. The GhIS provides annual list of valuers in good standing in Chana. However, there is no such list specifically for valuers in Accra. Further, the lists do not often have the address and location of valuers. This meant that the approach used was the most practical and suitable way of obtaining the required data and is similar to studies such as Boamah et al. (2012) and Baffour Awuah et al. (2013) in the study country. Prior to the 
questionnaire administration, the questionnaire was pre-tested using 4 experienced valuers to evaluate the questionnaire in terms of its coverage of what it envisaged to address, and the effectiveness of how the research variables were to be measured.

The lack of reliable sample frame impeded complete randomisation and to that extent was considered as a limitation. However, drawing respondents from different areas of professional practice and varied years of experience ensure that the results are representative of valuation practitioners in Ghana. Further, results from the stakeholder workshop and the questionnaire were discussed with the findings from the literature review. These were established to resonate with what is generally in the literature.

Views expressed by stakeholders at the workshop were recorded in a note book and they were analysed with insights from thematic analysis procedure. In so doing, the views were re-written in a clearer and more organised manner. Subsequently, they were read severally to identify significant viewpoints and common patterns that describe how the stakeholders described the research issue(s). This was done through the use of words, which were said often in the recordings as keywords and then noted the number of times they were used. Similar keywords were thereafter put together and reviewed to arrive at the outcomes. These were synthesised with the findings from the literature review. This partly enabled the identification of the property market data sources and the probable information that a suitable market data collection template should contain for the design of the questionnaire instrument.

The survey data were explored, cleaned, diagnosed and checked for consistency. Further, the scaled data (the extent of use of the market data sources by practitioners, the reliability of data from the sources for valuation practice in Ghana, the relevance of property market data collection template to the effective market data collection in the country as well as the information (fields) that a suitable property market data collection template should contain) were analysed using consensus/agreement around the mean analytical framework identified by Tastle and Wierman (2007), and subsequently modified by Tastle et. al (2009). This was to allow for analysing the consensus around a given target. Details of the formula are given as follows: 
The target used in this case was 5, the highest score on the likert scale. Details of the formula are given as follows:

$$
\operatorname{Agr}(X \mid 5)=1+\sum_{i=1}^{n} p i \log _{2}\left(1-\frac{\left|X_{i}-5\right|}{2 d_{X}}\right)
$$

Where:

Agr $=\quad$ The level of agreement on evaluation of an attribute;

$\mathrm{X}=\quad$ The scores;

$5=\quad$ The highest score;

$X_{i}=\quad$ Each score; and

$d_{X}=\quad$ The range of $\mathrm{X}\left(d_{X}=X_{\max }-X_{\min }\right)$

Generally, data generated from Likert scales are traditionally analysed using measures such as a weighted mean or weighted standard deviation. However, such approaches have been noted to be fraught with errors and present interpretation challenges particularly because Likert scales are ordinal measures. The consensus measure as given by the above formula is designed to accommodate the ordinal nature of Likert scale scores, and it ranges between 0 and 1.1 indicates complete agreement on an issue whereas 0 shows a complete lack of agreement. The measure, as applied to this study, captures the extent of the respondents' agreement towards the last option on the Likert scale ( 5 on a scale of $1-5$ ). Thus, 5 the highest score on the Likert scale was used as the target score.Therefore, for example, if all the respondents consider the data collection template as most useful by choosing 5 , then the consensus measure will result in 1 . 


\section{Conversely, if all the respondents do not consider the template as useful by} choosing 1 on the Likert scale, then the consensus measure will result in 0 .

\section{Research Findings}

Findings from the empirical aspect of the study are categorised into two parts. The first part reports the outcome from the stakeholder workshop. This is then followed by the second part, which presents findings from the questionnaire survey.

\section{Outcome from the Stakeholder Workshop}

The stakeholder workshop took place on February 25, 2015. The workshop was attended by over 50 valuation and estate surveyors from both public and private sector institutions. Five past presidents of the GhIS also attended the workshop. The workshop confirmed findings from the literature about the sources of property market data for valuation purpose in Ghana. These are: public and quasi-public institutions; property owners; property valuation practitioners and professional property consultancy firms, lawyers who deal with property transactions (professional colleagues); real estate developers; practitioners own databases; and informal real estate agents._The workshop also noted the media/online real estate transactions as an emerging property market data source in the country. However, participants opined that availability of reliable property market data is a challenge to valuation practice in the country and this has often resulted in the production of questionable valuations. They further expressed that reliability of property market data used for valuations is often dependent on its source. For example, they observed that unlike property market data obtained from state/public institutions, those obtained from real estate developers often appear more current, and that the media/online transactions could be used as a guide not as a real data source.

Participants made a number of suggestions to improve access to reliable property market data. First, it was_suggested that a standardised property market data collection template would significantly improve property market data collection practices in Ghana. Participants noted that such a template will be a good reference point to guide property market data collection and assist valuation practitioners to ask suitable questions during data 
collection. They also observed that the template could promote standardisation in data collection and enhance quick and easy access to information for valuation assignments. It was, however, recognised by participants that valuation practitioners need to be involved as much as possible in any effort to develop such a template to promote its use, and that the GhIS should take the lead in the development of such template. The participants further recommended the need for such a template to be: user friendly and adaptable to all property types and land uses; be easy to understand and use by all practitioners; be easy to access for use; and have fields to capture relevant information such as property numbers/identification, nature of transaction, parties to the transaction, agreed consideration and among other things (the detailed information that such a template should contain is given by Table $4 \underline{7}$ ).

Second, the workshop participants suggested the establishment of property market databank. It was agreed by the participants that the GhIS_should take the initiative to establish the databank and that its establishment should be supported by law. However, participants noted the need for the support of valuation practitioners to make it successful. They, therefore, recommended the provision of incentives such as discounts on fees to practitioners for access to data from such a databank to entice them to support it. Also, the workshop participants suggested that: there should be easy access to published data at a fee; there is a need for legal requirement to compel all property related transactions to be published; information sharing among practitioners should be encouraged; and_informal estate agents should be trained to enable them provide quality data._However, issues of whether or not the cost of obtaining reliable data should be transferred onto clients and how such costs should be assessed. This issue could not be resolved and merits further investigation.

\section{Findings from the Questionnaire Survey}

63.64\%_(70) of the 110 questionnaires administered were returned. However, some of the questions for a few of the questionnaires received were not answered. These were given the due consideration in the data analyses. The majority of the respondents had less than 15 years of professional experience. Indeed, $30 \%$ of the respondents had less than 5 years of professional experience compared to $24.29 \%, 15.71 \% 18.57 \%$ who had 
between 5 and 9,10 and 14, and above 25 years of professional experience respectively. Also, $25.71 \%$ of the respondents were employed in the government/public sector as against $28.57 \%$ who worked for private organisations and $45.71 \%$ who were private practitioners.

\section{Extent of Use and\& Reliability of Property Market Data Sources}

The seven property market data sources, which were identified from the | literature and the stakeholder consultation workshop namely:_public and quasi-public institutions; property owners; property valuation practitioners and professional property consultancy firms, lawyers who deal with property transactions (professional colleagues);real estate developers; practitioners own databases; informal real estate agents; and the media/on-line transactions were used in the survey. Analyses of the extent of use of these data sources and the reliability of the data they provide were undertaken with the analytical/formula outlined in the research methodology section after using a 5-point Likert scale to elicit the required responses. Tables 1 and 2 give details for the frequency of use of the data sources and the extent of reliability of the data produced by the sources respectively for all the respondents.:-

INSERT TABLES $1 \& 2$

Table 1 shows that obtaining market data from professional colleagues (Agrl5 $=0.94)$ was the most used data source compared to media/online real estate transactions, which was the least used(Agrl5 $=0.55$ ) by practitioners. Practitioners own database, public institutions, estate developers, estate agents and property owners were the second, third, fourth, fifth and the sixth most used data sources respectively. A possible reason for the high patronage of professional colleagues may be the ease with which practitioners obtain data from that source as they are colleagues 
and they know how to relate to each other to obtain what they want. Besides, practitioners are often more willing to provide their colleagues with market data as they may also need data or some form of assistance from them in the future. Conversely, the findings on the less used sources, in particular, estate agents and property owners may be due to lack of confidence in the reliability of the data provided and the usual non-availability of data respectively.

Strikingly, apart from the media, whose frequency of use corresponded to how the respondents rated its data reliability, there were variations in how the respondents rated the reliability of the data from the other property market data sources compared with their frequency of use (Table 2). Although professional colleagues' was the most used property market data source, its data was not perceived to be as reliable (Agrl5 $=0.89$ ) as practitioners own database (Agrl5 $=0.93$ ), which was rated as the most reliable (Table 2). This may be due to over-confidence of practitioners in the reliability of their own databases._Professional colleagues' was perceived as the second most reliable property market data source._A possible reason for this finding could be the confidence that professionals have in property market data collection and management capabilities of their colleagues.

Real estate developers, public institutions, property owners and estate agents were regarded as the third, fourth, fifth and the sixth most reliable data sources respectively (Table 2). The finding for real estate developers may be due to their ability to often provide current property market data as noted by the participants at the stakeholder workshop. Inadequate records keeping, and the tendency to provide out of date data and the bureaucratic process for provision of property market data may account for the finding on public institutions. Also, the practice of not disclosing details of real estate transactions by property owners, and the poor data collection and documentation for real estate transactions by real estate agents could be possible explanations for the findings on the other two property market data sources respectively.

Analysing the results per the nature of practice and years of professional experience of respondents, it was established that professional colleagues was the main source of data for the respondents whilst the media was the 


\begin{abstract}
least used data source (Table 3). However, mixed outcomes were noted on the frequency of use of the other data sources. For example, the findings show that whilst respondents in private practice and those engaged at public sector organisations considered public institutions as the second most used data source, respondents employed at private organisation considered own database as the second most used data source. With regard to years of professional experience, respondents with less than 5 years of experience considered estate developers as the second most used data source. Conversely, own database was the second most used data source for those with 5 years or more in experience. This finding is not surprising as practitioners with fewer years of experience are less likely to have developed extensive database on their own. Tables 3 and 4 present the frequency of use of the data sources by nature of practice and years of professional experience of respondents.
\end{abstract}

INSERT TABLE $3 \& 4$

Respondents for all the categories under nature of practice and years of professional experience also considered own database and professional colleagues as the most reliable and the second most reliable data sources respectively. The media was considered as the least reliable data source. The results on the reliability of the other data sources followed a $a$ similar pattern as those on the frequency of use. Tables 5 and 6 give further details.

INSERT TABLE $5 \& 6$

Relevance/Significance of Property Market Data Collection Template_and the Information (Fields) it should contain

Table 73 gives details on the findings from the survey results on the extent of relevance/significance of a suitable property market data collection template to effective and efficient market data collection for valuation purpose and 
the. Table 4 also details the ratings by importance for the information (fields) that a suitable property market data collection template should contain.

\section{INSERT TABLE $\underline{73}$}

$88.57 \%$ of the respondents answered the question on the relevance/significance of a suitable property market data collection template to effective and efficient market data collection for valuation practice. As can be seen from Table $\underline{7} 3$, an agreement score of 0.90 was obtained from the analysis. This signifies a high level of consensus among the respondents meaning that virtually all the respondents agreed that a suitable property market data collection template is relevant/significant or very relevant/significant to effective and efficient market data collection for valuation practice. This finding gives credence to the finding from the stakeholder workshop that a suitable property market data collection template could greatly assist in market data collection for valuation practice and in turn could help to redress the access to reliable market data problem in Ghana.

Analysis of the ratings on the importance/significance of the information/fields that a property market data collection template should contain demonstrates, to a large extent, that all the identified information is significant/important_for inclusion in a property market collection template (Table 74). However, date of transaction had the highest level of agreement on its significance (Agrl5 $=0.98$ ) compared to rooms' orientation, which had the least agreement $(A g r l 5=0.53)$. Overall, the results show that apart from size of property including land all the first few items (information) considered most significant are transaction data. The remaining factors relate to value attributes (property data). This is quite understandable and significant since it is often useful for appropriate property market data to be initially assembled subsequent to which the required analyses could be undertaken to ascertain the effect of value attributes as part of value determination process. 


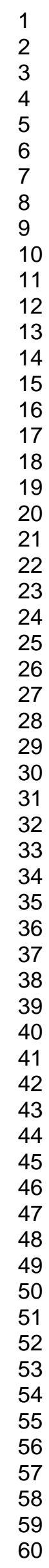

INSERT TABLE 4 


\section{Discussion of Findings}

Findings from both the literature review and the stakeholder workshop show that there are several sources from which valuers in Ghana obtain property market data to undertake valuations. The survey results established that valuers use all the identified market data sources, but professional colleagues as market data source is the most used compared to the media, which is the least used source. This further gives credence to the literature and corroborates studies such as Mends (2006). In terms of reliability, valuers considered their own databases as the most reliable but, to some extent, questioned the reliability of data from other sources and the media in particular. This supports Mahama and Antwi (2006), and Obeng-Odoom (2011) about the unreliability of market data often provided by estate agents. Further, the finding on the media confirms what was noted at the stakeholder workshop that data from this source is often used as a guide.

As established from the literature review and the stakeholder workshop, access to reliable and quality market data is often a challenge although valuers would like to use reliable market data for their valuations (Mahama and Antwi, 2006; Obeng-Odoom and Ameyaw, 2011). This situation is due to incomplete and scattered nature of data often resulting from administrative lapses; non-disclosure of details of property transactions due to confidentiality arrangements and the quest to evade taxes; data integrity concerns; and lack of requisite training and experience especially for estate agents to collect and manage market data_(Mends, 2006; Mahama and Antwi, 2006). Nevertheless, the study highlights sources of property market data for valuations, their reliability and associated problems. The study, therefore, provides useful input for any proposed initiatives to address the property market data challenge for valuation practitioners and other real estate sector stakeholders. It is, thus, useful to professional bodies such as the GhIS, RICS and organisation such as CASLE, Ghana's Lands Commission and the MMDAs among others.

Indeed, findings from the study highlight several things, which could help to address the property market data challenge in Ghana. The stakeholder workshop, for example, identified the usefulness of a suitable property market data collection template to effective and efficient market data collection. The workshop together with findings from the literature review 
further identified the information (fields) that a suitable property market data should contain. Establishment of databank was also recommended. The survey results corroborated the relevance of a data collection template to effective and efficient market data collection for valuation practice. The survey also determined the relative importance of the information that a suitable property market data collection template should contain. Additionally, the findings emphasise that reliable property market data should meet certain criteria such as dependability; stability; consistency; predictability, accuracy and completeness (Ge and Harfield, 2006; Gudat, 2010). This requires conscious and systematic approach to the collection and management of property market data for valuation practice.

This study based on the insights from the findings as demonstrated above developed a suitable template and guidelines (Figure 1) for effective and efficient market data collection (see appendix for a copy of the template). The template development follows the principle of consultation with valuers suggested at the stakeholder workshop. Also, it was developed with the information identified from the literature review and the stakeholder workshop, and confirmed by the survey results as information that a suitable property market data collection template should contain. The GhIS could, therefore, further refine the market data collection template to help standardise and guide meaningful property market data collection for valuation purposes. The guidelines for effective and efficient market data collection for valuation purpose emphasise conscious and systematic approach to collection and management of property market data for valuation practice. Thus, the development of the guidelines' is rooted in the qualities of reliable market data, the specific valuation purpose for which market data is required and the market data requirements to address the purpose. Figure 1 details the steps prescribed by the guidelines.

\section{INSERT FIGURE 1}

The property market data collection template and guidelines to effective and efficient data collection could help not only valuation practitioners, but also professionals and organisations in the built environment to collect and manage useful data and ultimately build effective and efficient databases for 
better decision-making. Further, they could help in promoting standardisation in valuation practice, which is essential to reduce errors in practice.

As stated in the introduction and the literature discussions, property market data is vital to the production of professional and ethical valuations (Gilbertson and Preston, 2005; Irohamet al., 2014; Ashaolu and Olaniran, 2016). Such valuations are also essential to the effective and efficient operations of the property market, inter-connected financial markets and national economies (Lorenz and Lützkendorf, 2008) as they are important tools for good governance, transparent business activities and promotion of investor confidence (Tretton, 2007). Findings from the research will help to improve access to market data and the property valuation practice in Ghana. This will also help to sustain and improve operations of the country's property markets, which are currently showing signs of growth, enhance investor confidence and activities, and ultimately lead to economic growth and development to alleviate poverty. Besides, the improvement in the data situation has the potential to reduce the time and the transaction cost valuers currently incur to access quality data, which are often nonexistent. The saved time and resources could be re-channelled to other productive activities to increase productivity.

Literature (Babawale and Ajayi, 2011; Otegbulu and Babawale, 2011; PWC, 2012; Ashaolu and Olaniran, 2016) shows that the property market data challenge and its adverse implications on property valuation is not peculiar to Ghana, but acrossthe entire SSA region. For example, Ashaolu and Olaniran (2016) note that Nigerian financial institutions are becoming weary of mortgage valuations prepared by Nigerians due to inadequate data and analysis. Therefore, although this study is not directly applicable to the rest of the SSA region its findings and outcome of the data collection template could offer useful lessons to practitioners and their professional bodies in the region to improve practice and market operations especially at a time when the region is beginning to attract global investment interest.

\section{Conclusions}

Reliable property market information is critical to the production of professional and ethical valuations. However, access to such information for valuation practice in Ghana is always a challenge. This may require a shift in the current practices of how market information is collected, managed, 
provided and accessed. This suggests a need to examine the existing property market data sources for valuation practice and the reliability of the data they produce to provide input into any initiative to redress the market data challenges faced by valuers in the country. This study, therefore, examined the sources and reliability of property market information for valuation practice in Ghana. The aim was to provide input into any initiative to address the difficulties faced by valuers to access property market information for valuation practice in the country.

The study established 7 sources of property market information for valuation practice in Ghana. These are: public and quasi-public institutions; property owners; property valuation practitioners and professional property consultancy firms, lawyers who deal with property transactions (professional colleagues); real estate developers; practitioners own databases; informal real estate agents; and the media/on-line transaction. In terms of reliability of the market data produced by the sources, valuers own databases was regarded as the most reliable source followed by the databases of their professional colleagues, real estate developers, public institutions, property owners, estate agents and the media in that order. Nevertheless, access to reliable property market information for valuation practice is always a challenge although valuers would always want to use reliable data. Further, it was found that the access to reliable property market information problem is due to incomplete and scattered nature of market data; non-disclosure of details of property transactions; data integrity concerns; and lack of requisite training and experience especially for estate agents to collect and manage market data.

Also, it was found that establishment of property market databank and a suitable property market data collection template are relevant to effective and efficient market data collection. Information that a suitable property market data collection template should contain were identified and their relative importance established. Additionally, the need for a conscious and systematic approach to market data collection taking into account requirements of a reliable market and which also suggest a need for practitioners to undergo continuous training was established. Funding cost of market data collection is, however, an issue, which requires further interrogation. 


\begin{abstract}
Using the foregoing insights, the study developed a property market collection template (see Figure 2 at the appendix) and guidelines for effective and efficient market data collection for improved valuation practice. The study, thus, provides useful input for any proposed initiatives to address the property market data challenge for valuation practitioners and other real estate sector stakeholders._t is, thus, useful to professional bodies such as the GhIS, RICS and organisation such as CASLE, Ghana's Lands Commission and the MMDAs among others. The foregoing has the potential to improve the access to market data and the property valuation practice in the country to promote effective and efficient market operations, investor confidence and activities, and lead to economic growth and development. Access to property market data improvement could also lead to increase in productivity through valuers re-channelling saved time and reduction in transaction costs from their current practice of devoting extensive time and resources to access quality data, which are often non-existent. Further, although the research is not directly applicable to the rest of the SSA region, given the peculiarity of the access to market data challenges and their adverse implications on valuation practice across the region, the findings and outcome from this research could offer useful lessons to the other countries in the region.
\end{abstract}

Based on the findings of the study and their implications, it is recommended that:

A property market databank should be created in Ghana. The GhIS with the support of its members should as a matter of urgency facilitate the creation of this data bank in collaboration with private sector and other stakeholders in the property market data industry such as valuation practitioners, public institutions, financial institutions, estate developers, estate agents and property owners.

Valuers/valuation surveyors should undergo regular relevant training to develop and enhance their knowledge, skills and capabilities to collect good quality property market data and produce high standard valuations._The GhIS as part of its CPD should organise such education and training programmes for practitioners. Also, such training programmes should be extended to local estate agents and other property market data collection and management institutions in the country. 
Last, but not the least, further research into funding for the cost of property market data collection in Ghana should be undertaken.

\section{Reference}

Aluko, B.T. (2004),"Privatization of public enterprises in Nigeria: Valuation issues andproblems", Journal of Business Economics and Management, Vol. 5 No.4, pp. 193-203.

Ashaolu, T.A. and Olaniran, M.O. (2016), "Valuers' strategies for coping with * the dearth of market datain two Nigerian cities: Ibadan and Abeokuta",

Pacific Rim Property Research Journal, Vol. 22, No. . 2, pp. 167-179.

Babawale, G.K. and Ajayi, C.A. (2011),"Variance in residential property valuation in Lagos, Nigeria",PropertyManagementVol. 29 No.3, pp. 222-237.

Baffour Awuah, K.G., Hammond, F.N. and Lamond, J.E. (2013),"The cost of land title formalization in Ghana", PropertyManagementVol. 31 No.4, pp. 389-403.

Boamah,N.A.,Gyimah,C.

and

Nelson,J.K.B. (2012),"Challengestotheenforcementofdevelopment control in theWaMunicipality", HabitatInternationaNol. 36,pp. 136-142.

Brown, G.R. (1992), "Valuation accuracy: Developing the economicissues", Journal of Property ResearchVol. 9 No. 3, pp. 199207.

Dunse, N., Jones, C., Orr, A. and Tarbet, H. (1998),"The extent and limitations of local commercial property marketdata",Journal of Property Valuation and InvestmentVol. 16 No.5, pp.455-473.

Ge, X.J. and Harfield, T. (2006),"The quality of data and data availability for property Research".

\section{Gilbertson, B., and Preston, D. (2005), A vision for valuation, RICS Leading} Edge Series. London: RICS.

Gough, K.V. and Yankson, P.W.K. (2000),"Land markets in African cities: The case of peri-urban Accra, Ghana",Urban StudiesVol. 3 No.13, pp. 2485 $-2500$.
Formatted: Font: Tw Cen MT, 12 pt Formatted: Left, Indent: Left: 0 ", First line: 0 ", Space After: 0 pt, Don't adjust space between Latin and Asian text, Don't adjust space between Asian text and numbers

Formatted: Font: Tw Cen MT, 12 pt Formatted: Font: Tw Cen MT, 12 pt, Italic Formatted: Font: Tw Cen MT, 12 pt Formatted: Font: Tw Cen MT, 12 pt Formatted: Font: Tw Cen MT, 12 pt

Formatted: Font: Tw Cen MT, 12 pt Formatted: Font: Tw Cen MT, 12 pt Formatted: Font: Tw Cen MT, 12 pt 
Gudat, R. (2010), "Collections of property market data for the valuation process: A Germany approach in an international context", Paper presented at FIC Congress 2010: Facing the challenges - building the capacity, Sydney, April 11-16.

Formatted: Indent: Left: 0", First line: $0 "$

Iroham, C.O., Ogunba, O.A. and Oloyede, S.A. (2014),"Effect of principal heuristics on accuracy of property valuation in Nigeria",Journal of Land and Rural Studies, Vol. 2 No. 1, pp. 89-111.

Mahama, C. and Antwi, A. (2006), Land and Property Markets in Ghana. RICS: London.

Mends, T.M. (2006), "Property valuation in Ghana: Constraints and contradictions", Paper presented at FIG Regional Conference on "Promoting Land Administration and Good Governance", March 8-11, La Palm Hotel, Accra.

Lorenz, D. and Lützkendorf, T. (2008), "Sustainability in property valuation: Theory and practice", Journal of Property Investment \& Finance, Vol. 26No. 6, pp. 482-521.

Obeng -Odoom, F. (2011),"Real estate agents in Ghana: A suitable case for regulation", RegionalStudiesVol. 43 No.3, pp. 403-416.

Obeng-Odoom, F. and Ameyaw, S. (2011),"The state of surveying profession in Africa: A Ghanaian perspective",Property Management, Vol. 29 No. 3, pp. 262-284.

Otegbulu, A. and Babawale, G.K. (2011), "Valuers' perception of potential sources of inaccuracy in plant and machinery valuation in Nigeria", Property Management, Vol. 29 No. 3, pp. 238-261.

Formatted: Indent: Left: $0 "$, First line: $0 "$

Peto, R. (1997),"Market information management for better valuations", Journal of Property Valuation \&lnvestment_Vol. 15 No.5, pp. $411-422$. 
PWC (2012), An African perspective: Valuation methodology survey (6thEdn.). Online at: http://www.pwc.co.za/en_ZA/za/assets/pdf/valuationmethodology-survey-2012.pdf [Accessed: August, 2015]

Tastle, W.J. and Wierman, M.J. (2007),“Consensus and dissention: A measure of ordinal dispersion", International Journal of Approximate ReasoningVol. 45, pp. 531-545.

Tastle, W.J., Boasson, E. and Wierman, M.J. (2009),"Assessing team performance in information systems projects", Information System Educational JournaNol. 7 No.90, pp. 1545-679X.

\footnotetext{
Tretton, D. (2007), "Where is the world of property valuation for taxation purposes going?", Journal of Property Investment \& Finance, Vol. 25 No. 5, pp. 482-514.

Wyatt, P.J. (1997),"The development of a GIS-basedproperty information system for real estate valuation",International Journal of Geographical Information Science, Vol. 11 No. 5, pp. 435-450.
} 
1

2

3

4

5

6

7

8

9

10

11

12

13

14

15

16

17

18

19

20

21

22

23

24

25

26

27

28

29

30

31

32

33

34

35

36

37

38

39

40

41

42

43

44

45

46

47

48

49

50

51

52

53

54

55

56

57

58

59

60

\section{INSERT FIGURE 2}


Table 1: Extent of Use of Property Market Data Sources

\begin{tabular}{|c|c|c|c|c|c|c|c|c|c|c|c|c|}
\hline \multirow[b]{2}{*}{ Source } & \multirow[b]{2}{*}{$\begin{array}{l}\mathbf{N} \\
\mathbf{0}\end{array}$} & \multicolumn{5}{|c|}{ Frequencies (\%) } & \multirow[b]{2}{*}{ Min } & \multirow[b]{2}{*}{$\operatorname{Max}$} & \multirow[b]{2}{*}{ Mean } & \multirow[b]{2}{*}{ Median } & \multirow[b]{2}{*}{ Mode } & \multirow[b]{2}{*}{ Agrl5 } \\
\hline & & 1 & 2 & 3 & 4 & 5 & & & & & & \\
\hline $\begin{array}{l}\text { Property } \\
\text { Owner }\end{array}$ & 70 & $\begin{array}{c}2.8 \\
6\end{array}$ & 21.43 & 37.14 & 18.57 & 20.00 & 1 & 5 & 3.31 & 3 & 3 & 0.636 \\
\hline $\begin{array}{l}\text { Estate } \\
\text { Agent }\end{array}$ & 69 & $\begin{array}{c}1.4 \\
5\end{array}$ & 7.25 & 34.78 & 39.13 & 17.39 & 1 & 5 & 3.64 & 4 & 4 & 0.717 \\
\hline $\begin{array}{l}\text { Professiona } \\
\text { Colleagues }\end{array}$ & 69 & $\begin{array}{c}0.0 \\
0\end{array}$ & 0.00 & 8.70 & 13.04 & 78.26 & 3 & 5 & 4.70 & 5 & 5 & 0.939 \\
\hline $\begin{array}{l}\text { Public } \\
\text { Institutions }\end{array}$ & 70 & $\begin{array}{c}0.0 \\
0\end{array}$ & 10.00 & 20.00 & 27.14 & 42.86 & 2 & 5 & 4.03 & 4 & 5 & 0.797 \\
\hline $\begin{array}{l}\text { Estate } \\
\text { Developers }\end{array}$ & 69 & $\begin{array}{c}1.4 \\
5\end{array}$ & 10.14 & 14.49 & 37.68 & 36.23 & 1 & 5 & 3.97 & 4 & 4 & 0.784 \\
\hline Media & 70 & $\begin{array}{l}12 . \\
86\end{array}$ & 24.29 & 25.71 & 27.14 & 10.00 & 1 & 5 & 2.97 & 3 & 4 & 0.548 \\
\hline $\begin{array}{l}\text { Own } \\
\text { Database }\end{array}$ & 66 & $\begin{array}{c}3.0 \\
3\end{array}$ & 6.06 & 10.61 & 30.30 & 50.00 & 1 & 5 & 4.18 & 4.5 & 5 & 0.826 \\
\hline
\end{tabular}

$1=$ Do not use at all $2=$ Rarely $3=$ Quite often $4=$ Often 5 Very Often

Table 2: Reliability of Property Market Data Sources

\begin{tabular}{ccccccccccccc}
\hline \multicolumn{1}{c}{ Source } & $\mathrm{N}$ & 1 & 2 & 3 & 4 & 5 & Min & Max & Mean & Median & Mode & Agrl5 \\
& 0 & & & & & & & & & & &
\end{tabular}




\begin{tabular}{|c|c|c|c|c|c|c|c|c|c|c|c|c|}
\hline Property & 70 & 2.8 & 10.00 & 42.86 & 28.57 & 15.71 & 1 & 5 & 3.44 & 3 & 3 & 0.671 \\
\hline Owner & & 6 & & & & & & & & & & \\
\hline \multicolumn{13}{|l|}{ Estate } \\
\hline \multirow[t]{2}{*}{ Agent } & 69 & 1.4 & 11.59 & 42.03 & 39.13 & 5.80 & 1 & 5 & 3.36 & 3 & 3 & 0.657 \\
\hline & & 5 & & & & & & & & & & \\
\hline \multicolumn{13}{|l|}{ Professiona } \\
\hline I & 70 & 0.0 & 0.00 & 7.14 & 42.86 & 50.00 & 3 & 5 & 4.43 & 4.5 & 5 & 0.888 \\
\hline \multicolumn{13}{|l|}{ Colleagues } \\
\hline \multicolumn{13}{|l|}{ Public } \\
\hline \multirow[t]{2}{*}{ Institutions } & 70 & 0.0 & 5.71 & 25.71 & 31.43 & 37.14 & 2 & 5 & 4.00 & 4 & 5 & 0.794 \\
\hline & & 0 & & & & & & & & & & \\
\hline \multicolumn{13}{|l|}{ Estate } \\
\hline \multirow[t]{2}{*}{ Developers } & 68 & 1.4 & 4.41 & 19.12 & 38.24 & 36.76 & 1 & 5 & 4.04 & 4 & 4 & 0.802 \\
\hline & & 7 & & & & & & & & & & \\
\hline \multirow[t]{2}{*}{ Media } & 67 & 7.4 & 22.39 & 50.75 & 17.91 & 1.49 & 1 & 5 & 2.84 & 3 & 3 & 0.528 \\
\hline & & 6 & & & & & & & & & & \\
\hline \multicolumn{13}{|l|}{ Own } \\
\hline \multirow[t]{2}{*}{ Database } & 65 & 0.0 & 0.00 & 3.08 & 32.31 & 64.62 & 3 & 5 & 4.62 & 5 & 5 & 0.925 \\
\hline & & 0 & & & & & & & & & & \\
\hline
\end{tabular}

$1=$ Very unreliable $2=$ Unreliable $3=$ Quite reliable $4=$ Reliable $5=$ Very reliable

\section{Table 3: Significance of Property/Market Data Collection Template}

\begin{tabular}{|c|c|c|c|c|c|c|c|c|c|c|c|c|}
\hline & \multirow[b]{2}{*}{$\mathbf{N}$} & \multicolumn{5}{|c|}{ Frequencies (\%) } & \multirow[b]{2}{*}{ Min } & \multirow[b]{2}{*}{ Max } & \multirow[b]{2}{*}{ Mean } & \multirow[b]{2}{*}{ Median } & \multirow{3}{*}{ Mode } & \multirow{3}{*}{ Agrl5 } \\
\hline & & +1 & $z$ & 3 & 4 & 5 & & & & & & \\
\hline & $\theta$ & & & & & & & & & & & \\
\hline Usefulness & 62 & 0.0 & 0.00 & 6.45 & 33.87 & 59.68 & 3 & 5 & 5 & 5 & 5 & 0.908 \\
\hline t & & $\theta$ & & & & & & & & & & \\
\hline Relevance & & & & & & & & & & & & \\
\hline
\end{tabular}

1 = Very insignificant 2 = Insignificant 3 =Quite significant $4=$ Significant 5 Very significant 
Fable-4: Relative Importance of Information/Fields that a Property Market Data Collection Template Should Contain

\begin{tabular}{|c|c|c|c|c|c|c|c|c|c|c|c|c|}
\hline \multirow[b]{2}{*}{ Field } & \multirow{2}{*}{$\begin{array}{l}\mathbf{N} \\
\boldsymbol{\theta}\end{array}$} & \multicolumn{5}{|c|}{ Frequencies (\%) } & \multirow[b]{2}{*}{ Min } & \multirow[b]{2}{*}{ Max } & \multirow[b]{2}{*}{ Mear } & \multirow[b]{2}{*}{ Median } & \multirow[b]{2}{*}{ Mode } & \multirow[b]{2}{*}{ Agf15 } \\
\hline & & 1 & $z$ & 3 & 4 & 5 & & & & & & \\
\hline Date of transaction & 70 & 0.00 & 0.00 & 0.00 & 11.43 & 88.57 & 4 & 5 & 4.89 & 5 & 5 & 0.978 \\
\hline Sale/purchase price/rent & 68 & 0.00 & 0.00 & 1.47 & 10.29 & 88.24 & 3 & 5 & 4.87 & 5 & 5 & 0.974 \\
\hline Size of property including land & 70 & 0.00 & 0.00 & 2.86 & 18.57 & 78.57 & 3 & 5 & 4.76 & 5 & 5 & 0.952 \\
\hline Property address/location & 70 & $\theta .00$ & 0.00 & 2.86 & 25.71 & 71.43 & 3 & 5 & 4.69 & 5 & 5 & 0.939 \\
\hline Title & 70 & 0.00 & 0.00 & 4.29 & 25.71 & 70.00 & 3 & 5 & 4.66 & 5 & 5 & 0.933 \\
\hline Neighbourhood & 69 & 0.00 & 0.00 & 5.80 & 24.64 & 69.57 & 3 & 5 & 4.64 & 5 & 5 & 0.928 \\
\hline Condition of property & 67 & 0.00 & 0.00 & 1.49 & 34.33 & 64.18 & 3 & 5 & 4.63 & 5 & 5 & 0.928 \\
\hline Term of interest & 70 & 0.00 & 2.86 & 7.14 & 22.86 & 67.14 & $z$ & 5 & 4.61 & 5 & 5 & 0.922 \\
\hline Nature of transaction & 70 & 0.00 & 0.00 & 5.71 & 40.00 & 54.29 & $z$ & 5 & 4.54 & 5 & 5 & 0.907 \\
\hline Accessibility & 70 & 0.00 & 0.00 & 11.59 & 30.43 & 57.97 & 3 & 5 & 4.49 & 5 & 5 & 0.899 \\
\hline Floor finish & 69 & 0.00 & 0.00 & 15.71 & 35.71 & 48.57 & 3 & 5 & 4.46 & 5 & 5 & 0.893 \\
\hline Walls & 70 & 0.00 & 0.00 & 15.71 & 35.71 & 48.57 & 3 & 5 & 4.33 & 4 & 5 & 0.866 \\
\hline Ceiling & 70 & 0.00 & 0.00 & 17.14 & 32.86 & 50.00 & 3 & 5 & 4.33 & 4 & 5 & 0.866 \\
\hline Roof & 70 & 0.00 & 0.00 & 17.14 & 34.29 & 48.57 & 3 & 5 & 4.33 & 4.5 & 5 & 0.866 \\
\hline Windows & 70 & 0.00 & 0.00 & 18.57 & 31.43 & 50.00 & 3 & 5 & 4.31 & 4 & 5 & 0.863 \\
\hline Doors & 70 & 2.94 & 0.00 & 11.76 & 38.24 & 47.06 & 3 & 5 & 4.31 & 4.5 & 5 & 0.862 \\
\hline Encumbrances & 34 & $\theta .00$ & $\theta .00$ & 20.29 & 39.13 & 40.58 & + & 5 & 4.26 & 4 & 5 & 0.848 \\
\hline External works & 69 & 0.00 & 0.00 & 18.57 & 42.86 & 38.57 & 3 & 5 & 4.20 & 4 & 5 & 0.840 \\
\hline Electricity & 70 & 0.00 & 1.43 & 21.43 & 35.71 & 41.43 & 3 & 5 & 4.20 & 4 & 4 & 0.840 \\
\hline Fixtures and fittings & 70 & 0.00 & 2.86 & 18.57 & 45.71 & 32.86 & $z$ & 5 & 4.17 & 4 & 5 & 0.833 \\
\hline Pipe borne water & 70 & 0.00 & 1.43 & 25.71 & 37.14 & 35.71 & $z$ & 5 & 4.09 & 4 & 4 & 0.815 \\
\hline Age of property & 70 & 0.00 & 2.86 & 34.29 & 27.14 & 35.71 & $z$ & 5 & 4.07 & 4 & 4 & 0.812 \\
\hline Registration status & 70 & 1.43 & 4.29 & 22.86 & 42.86 & 28.57 & $z$ & 5 & 3.96 & 4 & 5 & 0.786 \\
\hline Number of rooms & 70 & 0.00 & 7.25 & 27.54 & 39.13 & 26.09 & + & 5 & 3.93 & 4 & 4 & 0.779 \\
\hline Planning scheme & 69 & 0.00 & 5.80 & 33.33 & 31.88 & 28.99 & $z$ & 5 & 3.84 & 4 & 4 & 0.761 \\
\hline Building permit status & 69 & 1.45 & 4.35 & 31.88 & 39.13 & 23.19 & $z$ & 5 & 3.84 & 4 & 3 & 0.761 \\
\hline Proximity to other social amenities & 69 & 2.90 & 11.59 & 20.29 & 34.78 & 30.43 & + & 5 & 3.78 & 4 & 4 & 0.748 \\
\hline Rent passing & 69 & 1.45 & 7.25 & 34.78 & 33.33 & 23.19 & + & 5 & 3.78 & 4 & 4 & 0.741 \\
\hline Parties to transaction & 69 & 8.57 & 7.14 & 40.00 & 25.71 & 18.57 & + & 5 & 3.70 & 4 & 3 & 0.728 \\
\hline Telephone & 70 & 12.86 & 18.57 & 40.00 & 24.29 & 4.29 & + & 5 & 3.39 & 3 & 3 & 0.650 \\
\hline Rooms' orientation & 70 & 0.00 & 2.86 & 7.14 & 22.86 & 67.14 & + & 5 & 2.89 & 3 & 3 & 0.533 \\
\hline
\end{tabular}

$1=$ Very insignificant 2 = Insignificant $3=$ Quite significant $4=$ Significant 5 Very significant 
Table 3: Extent of Use of Property Market Data Sources by Nature of Professional Practice

\begin{tabular}{|llllllll} 
& \multicolumn{10}{c}{ Frequency (\%) } \\
\cline { 2 - 7 } Source & $\mathrm{N}$ & 1 & 2 & 3 & 4 & 5 & Agrl.5 \\
\hline
\end{tabular}

\section{Private Practice}

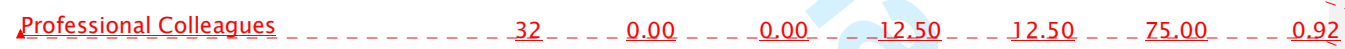

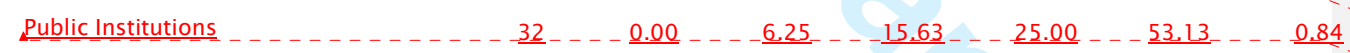

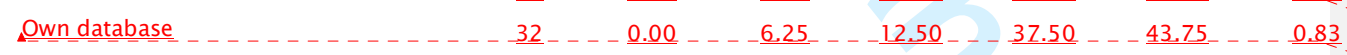

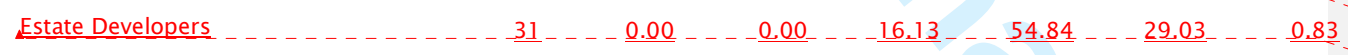

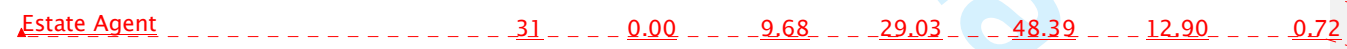

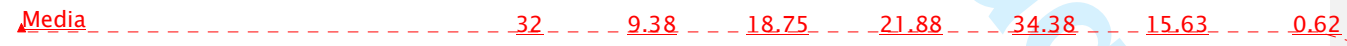

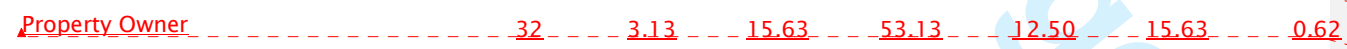

Publiclic Lovernment Institution

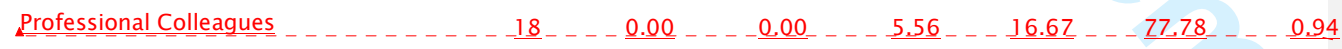

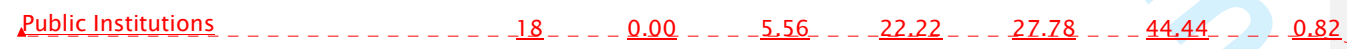

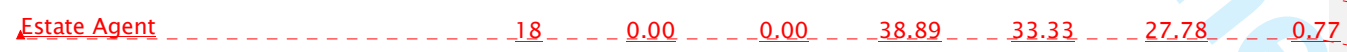

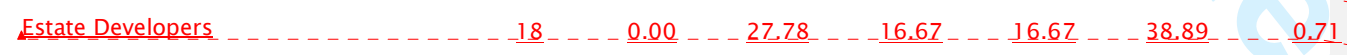

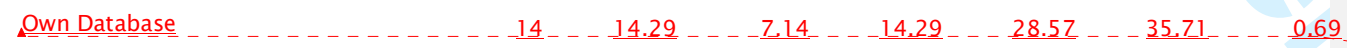

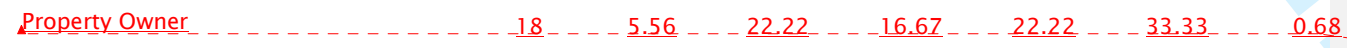

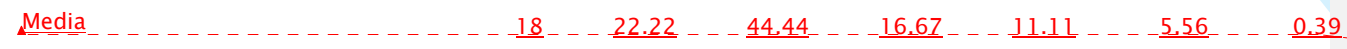

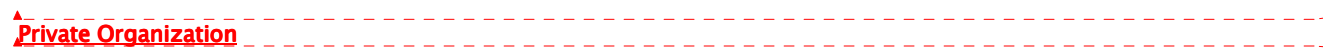

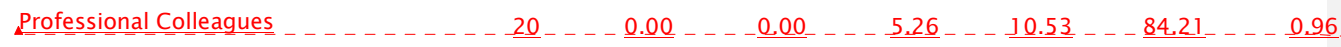

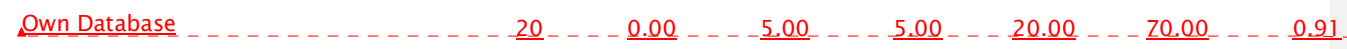

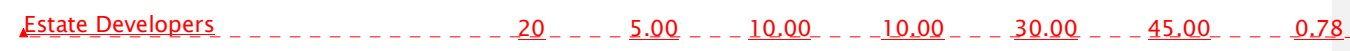

\begin{tabular}{|l|}
\hline Formatted: Font: $8 \mathrm{pt}$ \\
\hline Formatted: Font: $8 \mathrm{pt}$ \\
\hline Formatted: Font: Arial, $8 \mathrm{pt}$ \\
\hline Formatted: Font: $8 \mathrm{pt}$ \\
\hline Formatted: Font: $8 \mathrm{pt}$ \\
\hline Formatted: Font: $8 \mathrm{pt}$ \\
\hline Formatted: Font: $8 \mathrm{pt}$ \\
\hline Formatted: Font: $8 \mathrm{pt}$ \\
\hline Formatted: Font: $8 \mathrm{pt}$ \\
\hline Formatted: Font: $8 \mathrm{pt}$ \\
\hline Formatted: Font: $8 \mathrm{pt}$ \\
\hline Formatted: Font: $8 \mathrm{pt}$ \\
\hline Formatted: Font: $8 \mathrm{pt}$ \\
\hline Formatted: Font: $8 \mathrm{pt}$ \\
\hline Formatted: Font: $8 \mathrm{pt}$ \\
\hline Formatted: Font: $8 \mathrm{pt}$ \\
\hline Formatted: Font: $8 \mathrm{pt}$ \\
\hline Formatted: Font: $8 \mathrm{pt}$ \\
\hline Formatted: Font: $8 \mathrm{pt}$ \\
\hline Formatted: Font: $8 \mathrm{pt}$ \\
\hline
\end{tabular}




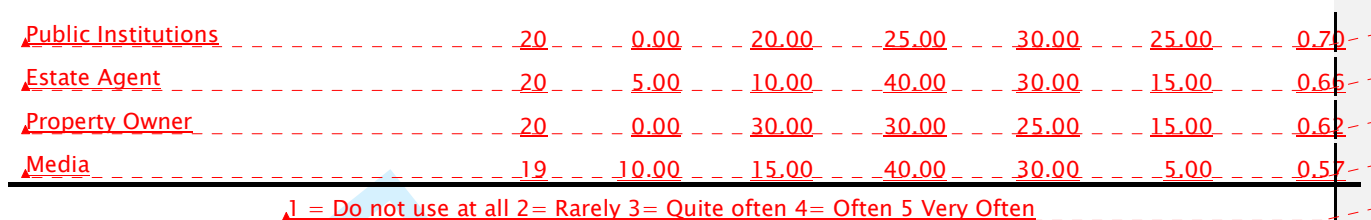

13

14

15

16

17

18

19

20

21

22

23

24

25

26

27

28

29

30

31

32

33

34

35

36

37

38

39

40

41

42

43

44

45

46

47

48

49

50

51

52

53

54

55

56

57

58

59

60
Table 4: Extent of Use of Property Market Data Sources by Years of Experience

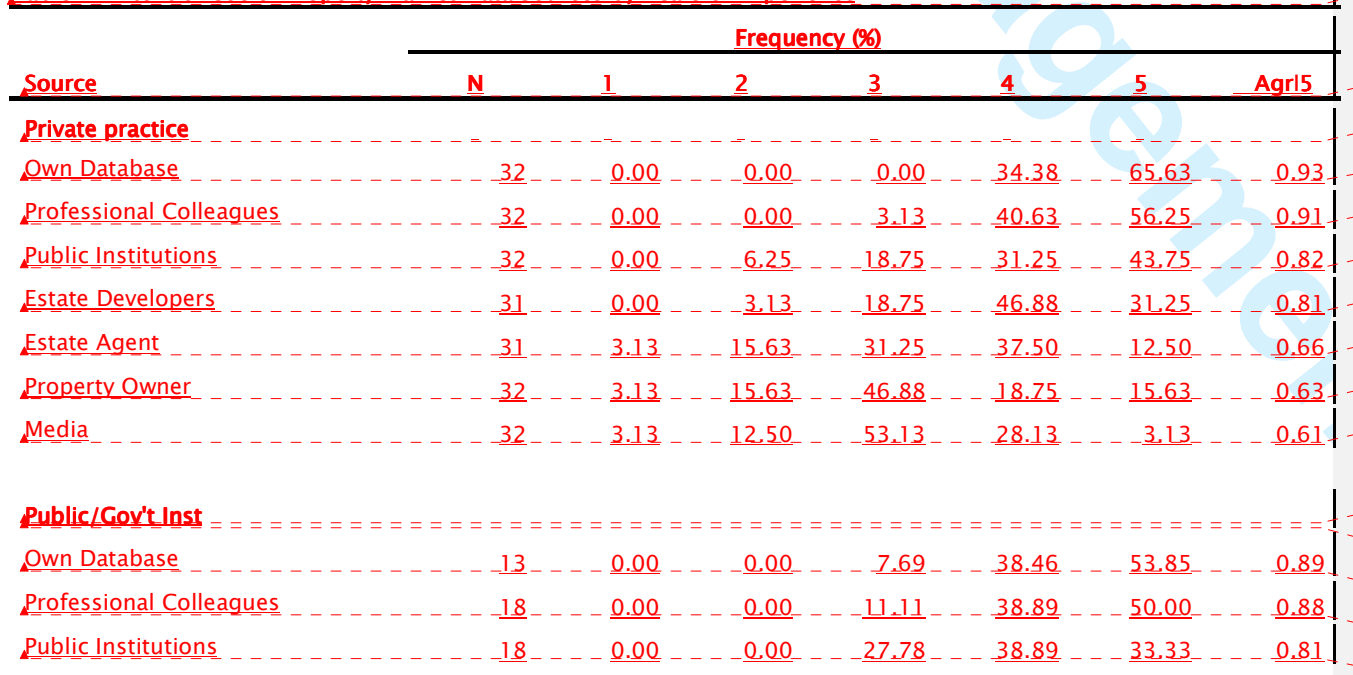

Formatted: Font: $8 \mathrm{pt}$
Formatted: Font: $8 \mathrm{pt}$
Formatted: Font: $8 \mathrm{pt}$
Formatted: Font: $8 \mathrm{pt}$
Formatted: Font: $8 \mathrm{pt}$

Formatted: Font: $8 \mathrm{pt}$

Formatted: Font: $8 \mathrm{pt}$

Formatted: Font: $8 \mathrm{pt}$

Formatted: Font: $8 \mathrm{pt}$

Formatted: Font: $8 \mathrm{pt}$

Formatted: Font: $8 \mathrm{pt}$

Formatted: Font: $8 \mathrm{pt}$

Formatted: Font: $8 \mathrm{pt}$

Formatted: Font: $8 \mathrm{pt}$

Formatted: Font: $8 \mathrm{pt}$

Formatted: Font: $8 \mathrm{pt}$

Formatted: Font: $8 \mathrm{pt}$

Formatted: Font: $8 \mathrm{pt}$

Formatted: Font: $8 \mathrm{pt}$

Formatted: Font: $8 \mathrm{pt}$ 


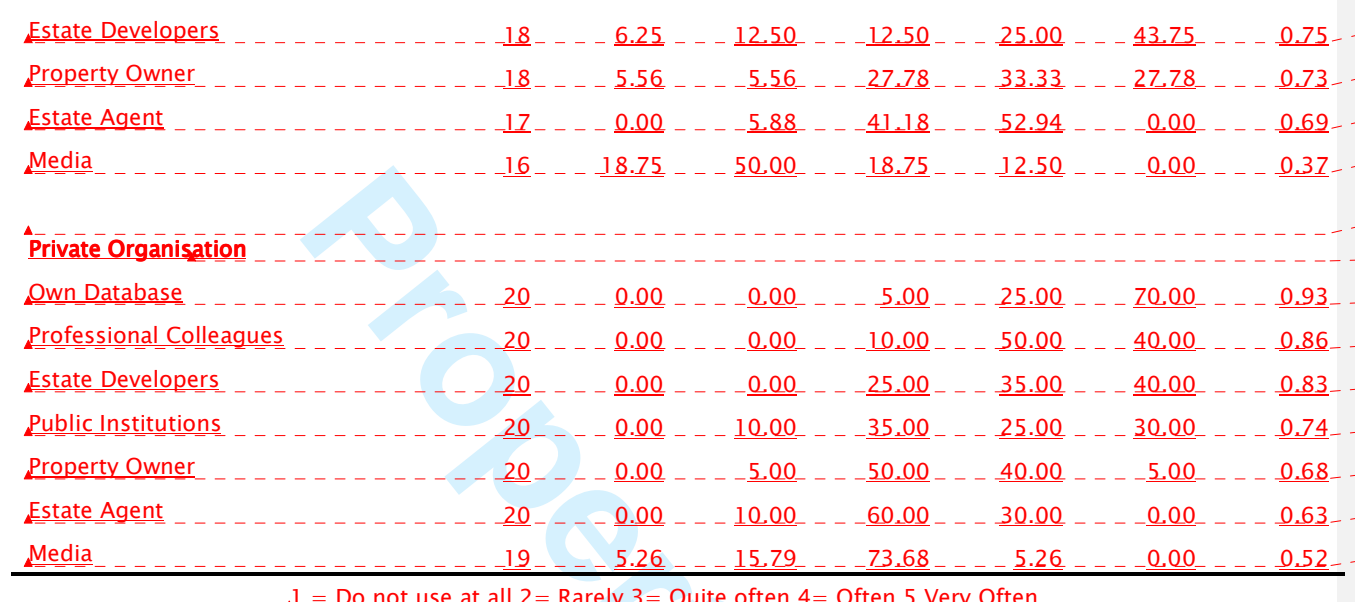

Table 5: Reliability of Property Market Data Sources by Nature of Professional Practice

\begin{tabular}{|llllllll}
\hline & \multicolumn{8}{|c}{ Frequency (\%) } \\
\cline { 2 - 8 } Source & N & 1 & $\underline{3}$ & $\underline{3}$ & 4 & Agrl5 \\
\hline
\end{tabular}

\section{Below 5 years}

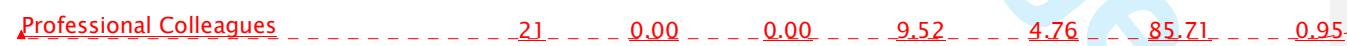

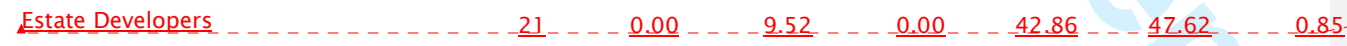

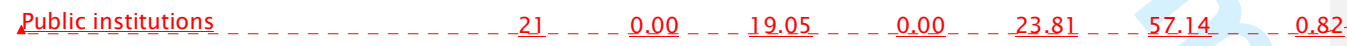

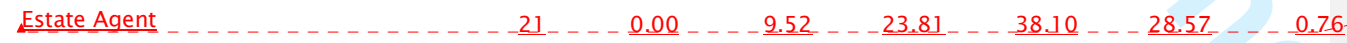

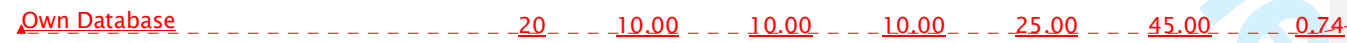

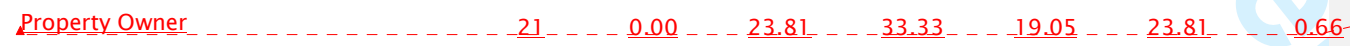

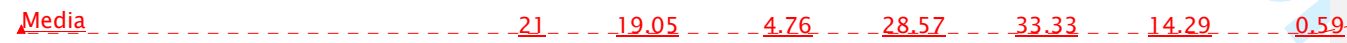

\section{Between 5 and 15 years}

Professional Colleaques Own Database Public Institutions Estate Developers Estate Agent
Formatted: Font: $8 \mathrm{pt}$ Formatted: Font: $8 \mathrm{pt}$ Formatted: Font: $8 \mathrm{pt}$ Formatted: Font: $8 \mathrm{pt}$

Formatted: Font: $8 \mathrm{pt}$ Formatted: Font: $8 \mathrm{pt}$ Formatted: Font: $8 \mathrm{pt}$ Formatted: Font: $8 \mathrm{pt}$ Formatted: Font: $8 \mathrm{pt}$ Formatted: Font: $8 \mathrm{pt}$ Formatted: Font: $8 \mathrm{pt}$ Formatted: Font: $8 \mathrm{pt}$ Formatted: Font: $8 \mathrm{pt}$ Formatted: Font: $8 \mathrm{pt}$

Formatted: Font: $8 \mathrm{pt}$

\begin{tabular}{l} 
Formatted: Font: $8 \mathrm{pt}$ \\
Formatted: Font: $8 \mathrm{pt}$ \\
Formatted: Font: $8 \mathrm{pt}$ \\
Formatted: Font: $8 \mathrm{pt}$ \\
Formatted: Font: $8 \mathrm{pt}$ \\
Formatted: Font: $8 \mathrm{pt}$ \\
Formatted: Font: $8 \mathrm{pt}$ \\
Formatted: Font: $8 \mathrm{pt}$ \\
Formatted: Font: $8 \mathrm{pt}$ \\
Formatted: Font: $8 \mathrm{pt}$ \\
\hline Formatted: Font: $8 \mathrm{pt}$ \\
\hline
\end{tabular}




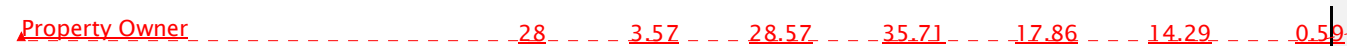

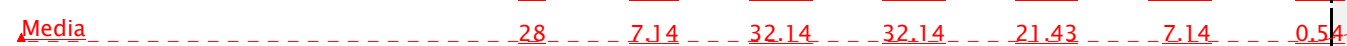

\section{Âbove $1 \overline{1}$ years}

Professional Colleaques

Own Database

Public Institutions

Estate Developers

Estate Agent

Property Owner

Media

$$
-\underline{28}-\ldots \underline{\underline{7.14}} \ldots-\underline{\underline{32.14}}---\underline{32.14}-\ldots \underline{21.43}-\ldots \underline{\underline{7.14}}-\ldots-\underline{0.54}
$$

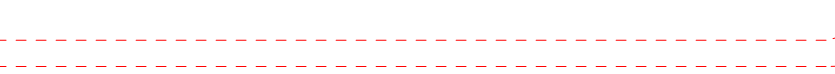

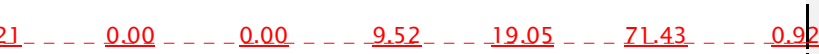

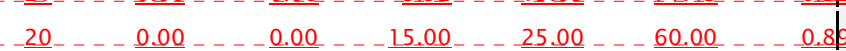

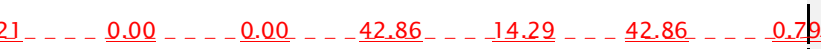
$20-\ldots \frac{0.00}{0.00}-\frac{10.00}{5.00}--\underline{15.00}--\underline{\underline{50.00}}-\ldots \underline{25.00}--\underline{0.77}$

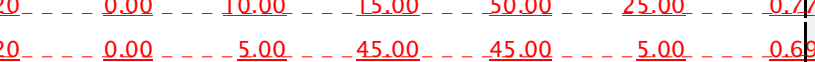

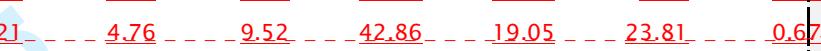
21 $2 \underline{28.57}$

$1=$ Very unreliable $2=$ Unreliable $3=$ Quite reliable $4=$ Reliable $5=$ Very reliable

Table 6: Reliability of Property Market Data Sources by Nature of Years of Experience

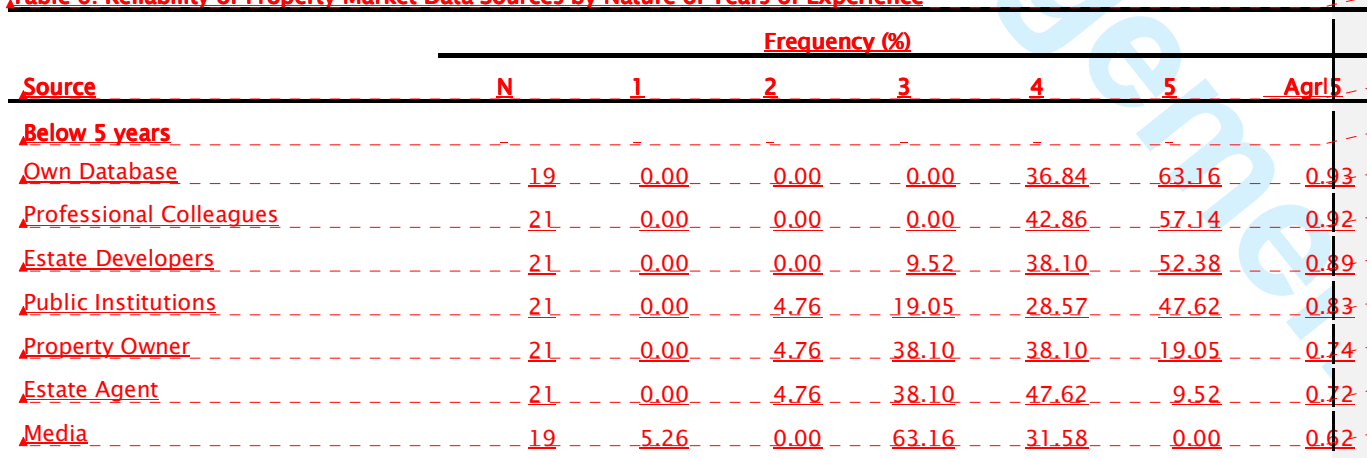

Between 5 and 15 years

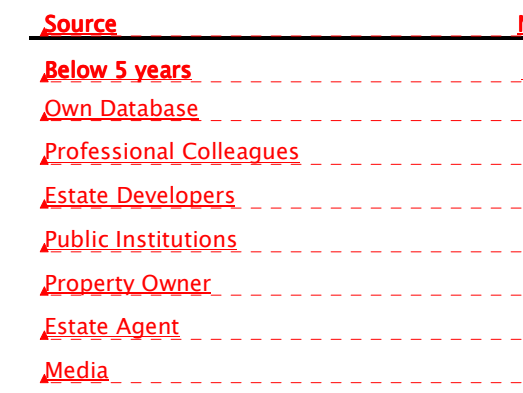

Own Database

$\underline{26}---\underline{0.00}$

0.00

$-\underline{7.6}$

$-\underline{28}---\underline{0.00}$

0.00

14.29

\begin{tabular}{l} 
Formatted: Font: $8 \mathrm{pt}$ \\
Formatted: Font: $8 \mathrm{pt}$ \\
Formatted: Font: $8 \mathrm{pt}$ \\
Formatted: Font: $8 \mathrm{pt}$ \\
Formatted: Font: $8 \mathrm{pt}$ \\
Formatted: Font: $8 \mathrm{pt}$ \\
Formatted: Font: $8 \mathrm{pt}$ \\
Formatted: Font: $8 \mathrm{pt}$ \\
Formatted: Font: $8 \mathrm{pt}$ \\
Formatted: Font: $8 \mathrm{pt}$ \\
Formatted: Font: $8 \mathrm{pt}$ \\
\hline
\end{tabular}

\begin{tabular}{|l}
\hline Formatted: Font: $8 \mathrm{pt}$ \\
\hline Formatted: Font: $8 \mathrm{pt}$ \\
\hline Formatted: Font: $8 \mathrm{pt}$ \\
\hline Formatted: Font: $8 \mathrm{pt}$ \\
\hline Formatted: Font: $8 \mathrm{pt}$ \\
\hline Formatted: Font: $8 \mathrm{pt}$ \\
\hline Formatted: Font: $8 \mathrm{pt}$ \\
\hline Formatt: Font: $8 \mathrm{pt}$ \\
\hline
\end{tabular}




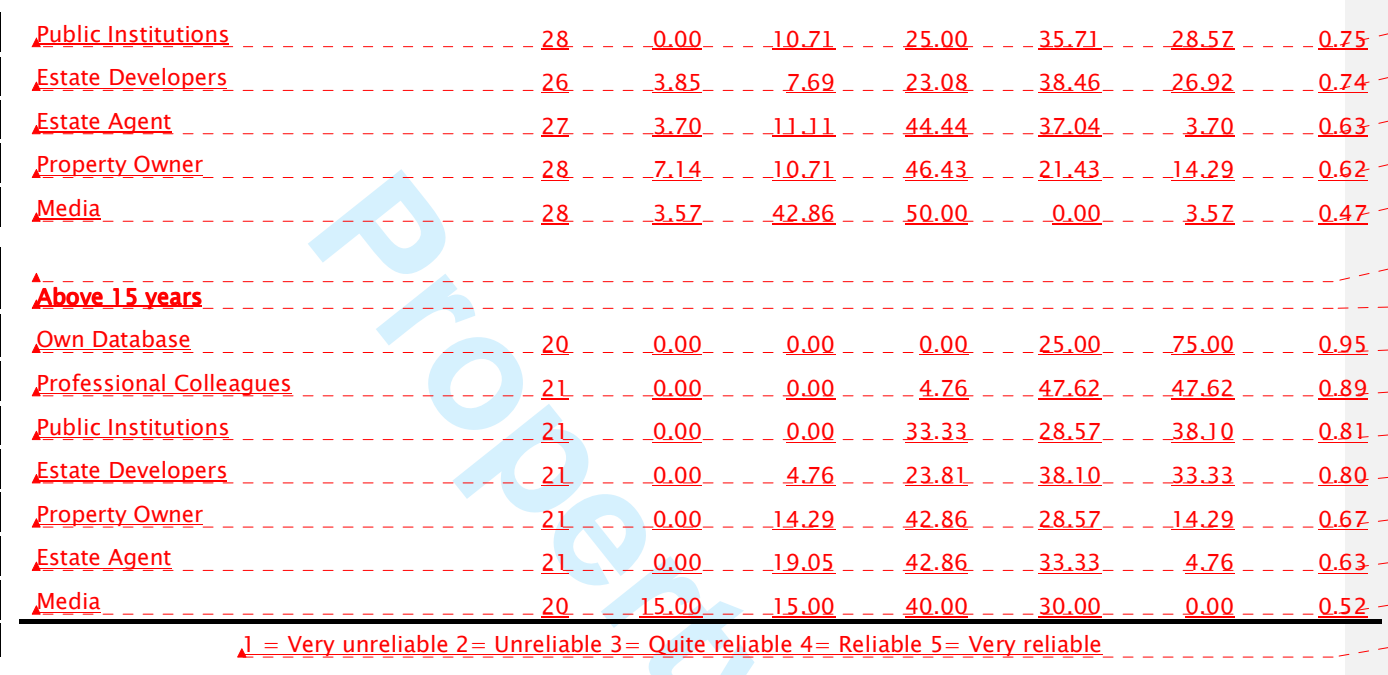

Formatted: Font: $8 \mathrm{pt}$

Formatted: Font: $8 \mathrm{pt}$

Formatted: Font: $8 \mathrm{pt}$

Formatted: Font: $8 \mathrm{pt}$

Formatted: Font: $8 \mathrm{pt}$

Formatted: Font: $8 \mathrm{pt}$

Formatted: Font: $8 \mathrm{pt}$

Formatted: Font: $8 \mathrm{pt}$

Formatted: Font: $8 \mathrm{pt}$

Formatted: Font: $8 \mathrm{pt}$

Formatted: Font: $8 \mathrm{pt}$

Formatted: Font: $8 \mathrm{pt}$

Formatted: Font: $8 \mathrm{pt}$

Formatted: Font: $8 \mathrm{pt}$

Formatted: Font: $8 \mathrm{pt}$ 
Table 7: Usefulness of Data Template and Relative Importance of Information/Fields that a Property Market Data Collection Template Should

\begin{tabular}{|c|c|c|c|c|c|c|c|c|c|c|c|c|}
\hline \multicolumn{13}{|c|}{ Contain } \\
\hline Field & $\begin{array}{l}\underline{\mathbf{N}} \\
\underline{0}\end{array}$ & 1 & $\underline{2}$ & $\underline{3}$ & $\underline{4}$ & $\underline{5}$ & $\underline{\text { Min }}$ & $\underline{\text { Max }}$ & Mean & Median & Mode & Agrl5 \\
\hline \multicolumn{13}{|c|}{ Panel A: Usefulness of Data Collection Template } \\
\hline Usefulness/Relevance & $\underline{62}$ & $\underline{0.00}$ & $\underline{0.00}$ & $\underline{6.45}$ & $\underline{33.87}$ & $\underline{59.68}$ & $\underline{3}$ & $\underline{5}$ & $\underline{5}$ & $\underline{5}$ & $\underline{5}$ & $\underline{0.908}$ \\
\hline \multicolumn{13}{|c|}{ Panel B: Relative Importance of Information/Field in a Property Market Data Collection Template } \\
\hline Date of transaction & $\underline{70}$ & $\underline{0.00}$ & $\underline{0.00}$ & $\underline{0.00}$ & $\underline{11.43}$ & $\underline{88.57}$ & $\underline{4}$ & $\underline{5}$ & $\underline{4.89}$ & $\underline{5}$ & $\underline{5}$ & $\underline{0.978}$ \\
\hline Sale/purchase price/rent & $\underline{68}$ & $\underline{0.00}$ & $\underline{0.00}$ & 1.47 & 10.29 & $\underline{88.24}$ & $\underline{3}$ & $\underline{5}$ & $\underline{4.87}$ & $\underline{5}$ & $\underline{5}$ & $\underline{0.974}$ \\
\hline Size of property including land & $\underline{70}$ & $\underline{0.00}$ & $\underline{0.00}$ & $\underline{2.86}$ & 18.57 & 78.57 & $\underline{3}$ & $\underline{5}$ & $\underline{4.76}$ & $\underline{5}$ & $\underline{5}$ & $\underline{0.952}$ \\
\hline Property address/location & $\underline{70}$ & $\underline{0.00}$ & $\underline{0.00}$ & $\underline{2.86}$ & 25.71 & 71.43 & $\underline{3}$ & $\underline{5}$ & 4.69 & $\underline{5}$ & $\underline{5}$ & $\underline{0.939}$ \\
\hline$\underline{\text { Title }}$ & $\underline{70}$ & $\underline{0.00}$ & $\underline{0.00}$ & $\underline{4.29}$ & 25.71 & $\underline{70.00}$ & $\underline{3}$ & $\underline{5}$ & $\underline{4.66}$ & $\underline{5}$ & $\underline{5}$ & $\underline{0.933}$ \\
\hline Neighbourhood & $\underline{69}$ & $\underline{0.00}$ & $\underline{0.00}$ & $\underline{5.80}$ & 24.64 & 69.57 & $\underline{3}$ & $\underline{5}$ & 4.64 & $\underline{5}$ & $\underline{5}$ & $\underline{0.928}$ \\
\hline Condition of property & 67 & $\underline{0.00}$ & $\underline{0.00}$ & 1.49 & 34.33 & 64.18 & $\underline{3}$ & $\underline{5}$ & 4.63 & $\underline{5}$ & $\underline{5}$ & 0.928 \\
\hline$\underline{\text { Term of interest }}$ & $\underline{70}$ & $\underline{0.00}$ & $\underline{2.86}$ & $\underline{7.14}$ & $\underline{22.86}$ & $\underline{67.14}$ & $\underline{2}$ & $\underline{5}$ & $\underline{4.61}$ & $\underline{5}$ & $\underline{5}$ & $\underline{0.922}$ \\
\hline Nature of transaction & $\underline{70}$ & $\underline{0.00}$ & $\underline{0.00}$ & $\underline{5.71}$ & $\underline{40.00}$ & $\underline{54.29}$ & $\underline{2}$ & $\underline{5}$ & 4.54 & $\underline{5}$ & $\underline{5}$ & $\underline{0.907}$ \\
\hline Accessibility & $\underline{70}$ & $\underline{0.00}$ & $\underline{0.00}$ & 11.59 & $\underline{30.43}$ & $\underline{57.97}$ & $\underline{3}$ & $\underline{5}$ & $\underline{4.49}$ & $\underline{5}$ & $\underline{5}$ & $\underline{0.899}$ \\
\hline Floor finish & $\underline{69}$ & $\underline{0.00}$ & $\underline{0.00}$ & 15.71 & 35.71 & 48.57 & $\underline{3}$ & $\underline{5}$ & 4.46 & $\underline{5}$ & $\underline{5}$ & $\underline{0.893}$ \\
\hline Walls & $\underline{70}$ & $\underline{0.00}$ & $\underline{0.00}$ & 15.71 & 35.71 & 48.57 & $\underline{3}$ & $\underline{5}$ & 4.33 & $\underline{4}$ & $\underline{5}$ & $\underline{0.866}$ \\
\hline Ceiling & $\underline{70}$ & $\underline{0.00}$ & $\underline{0.00}$ & 17.14 & 32.86 & $\underline{50.00}$ & $\underline{3}$ & $\underline{5}$ & 4.33 & $\underline{4}$ & $\underline{5}$ & $\underline{0.866}$ \\
\hline$\underline{\text { Roof }}$ & $\underline{70}$ & $\underline{0.00}$ & $\underline{0.00}$ & 17.14 & $\underline{34.29}$ & $\underline{48.57}$ & $\underline{3}$ & $\underline{5}$ & $\underline{4.33}$ & 4.5 & $\underline{5}$ & $\underline{0.866}$ \\
\hline Windows & $\underline{70}$ & $\underline{0.00}$ & $\underline{0.00}$ & 18.57 & $\underline{31.43}$ & $\underline{50.00}$ & $\underline{3}$ & $\underline{5}$ & $\underline{4.31}$ & $\underline{4}$ & $\underline{5}$ & $\underline{0.863}$ \\
\hline Doors & $\underline{70}$ & $\underline{2.94}$ & $\underline{0.00}$ & 11.76 & $\underline{38.24}$ & $\underline{47.06}$ & $\underline{3}$ & $\underline{5}$ & $\underline{4.31}$ & $\underline{4.5}$ & $\underline{5}$ & $\underline{0.862}$ \\
\hline Encumbrances & $\underline{34}$ & $\underline{0.00}$ & $\underline{0.00}$ & $\underline{20.29}$ & $\underline{39.13}$ & $\underline{40.58}$ & $\underline{1}$ & $\underline{5}$ & $\underline{4.26}$ & $\underline{4}$ & $\underline{5}$ & $\underline{0.848}$ \\
\hline External works & $\underline{69}$ & $\underline{0.00}$ & $\underline{0.00}$ & 18.57 & $\underline{42.86}$ & 38.57 & $\underline{3}$ & $\underline{5}$ & $\underline{4.20}$ & $\underline{4}$ & $\underline{5}$ & $\underline{0.840}$ \\
\hline Electricity & $\underline{70}$ & $\underline{0.00}$ & $\underline{1.43}$ & $\underline{21.43}$ & $\underline{35.71}$ & $\underline{41.43}$ & $\underline{3}$ & $\underline{5}$ & $\underline{4.20}$ & $\underline{4}$ & 4 & $\underline{0.840}$ \\
\hline$\underline{\text { Fixtures and fittings }}$ & $\underline{70}$ & $\underline{0.00}$ & $\underline{2.86}$ & $\underline{18.57}$ & $\underline{45.71}$ & $\underline{32.86}$ & $\underline{2}$ & $\underline{5}$ & $\underline{4.17}$ & $\underline{4}$ & $\underline{5}$ & $\underline{0.833}$ \\
\hline Pipe borne water & $\underline{70}$ & $\underline{0.00}$ & $\underline{1.43}$ & $\underline{25.71}$ & $\underline{37.14}$ & $\underline{35.71}$ & $\underline{2}$ & $\underline{5}$ & $\underline{4.09}$ & $\underline{4}$ & $\underline{4}$ & $\underline{0.815}$ \\
\hline Age of property & $\underline{70}$ & $\underline{0.00}$ & $\underline{2.86}$ & $\underline{34.29}$ & $\underline{27.14}$ & $\underline{35.71}$ & $\underline{2}$ & $\underline{5}$ & $\underline{4.07}$ & $\underline{4}$ & $\underline{4}$ & $\underline{0.812}$ \\
\hline Registration status & $\underline{70}$ & 1.43 & $\underline{4.29}$ & $\underline{22.86}$ & 42.86 & 28.57 & $\underline{2}$ & $\underline{5}$ & $\underline{3.96}$ & $\underline{4}$ & $\underline{5}$ & $\underline{0.786}$ \\
\hline Number of rooms & $\underline{70}$ & $\underline{0.00}$ & $\underline{7.25}$ & $\underline{27.54}$ & $\underline{39.13}$ & $\underline{26.09}$ & 1 & $\underline{5}$ & $\underline{3.93}$ & 4 & $\underline{4}$ & $\underline{0.779}$ \\
\hline Planning scheme & $\underline{69}$ & $\underline{0.00}$ & $\underline{5.80}$ & $\underline{33.33}$ & $\underline{31.88}$ & $\underline{28.99}$ & $\underline{2}$ & $\underline{5}$ & $\underline{3.84}$ & $\underline{4}$ & $\underline{4}$ & $\underline{0.761}$ \\
\hline Building permit status & $\underline{69}$ & $\underline{1.45}$ & $\underline{4.35}$ & $\underline{31.88}$ & $\underline{39.13}$ & $\underline{23.19}$ & $\underline{2}$ & $\underline{5}$ & $\underline{3.84}$ & $\underline{4}$ & $\underline{3}$ & $\underline{0.761}$ \\
\hline
\end{tabular}




\section{Property Management}

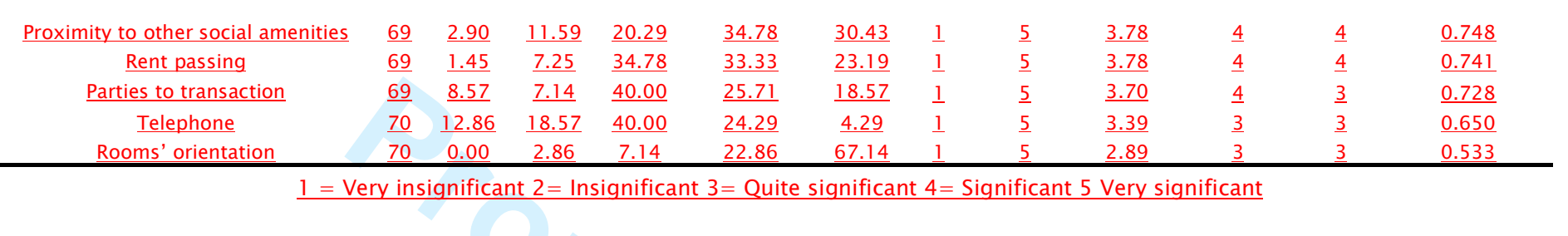

Formatted: Font: Tw Cen MT, 8 pt 


\section{Response to Reviewers' Comments}

\begin{tabular}{|c|c|}
\hline Observations & Response \\
\hline \multicolumn{2}{|c|}{ Reviewer 1} \\
\hline $\begin{array}{l}\text { 3. The research method can be enhanced. } \\
\text { At page 14, the author stated the } \\
\text { formula which calculated the target } \\
\text { score. It would be better if there is more } \\
\text { discussion on the relevance of this } \\
\text { formula to the study. Also, it would be } \\
\text { important to discuss how the } \\
\text { questionnaire data and the workshop } \\
\text { data analysed. } \\
\text { It is also essential to add the discussion } \\
\text { on reliability, validity and generalisability } \\
\text { as well as limitation of this research. }\end{array}$ & $\begin{array}{l}\text { This has been fully addressed at the research } \\
\text { methodology section of the paper. }\end{array}$ \\
\hline $\begin{array}{l}\text { 4. The research findings can be more } \\
\text { thorough. For example, it would good } \\
\text { there is more discussion on the findings } \\
\text { from respondents of different } \\
\text { professional and demographic } \\
\text { background. The discussion of research } \\
\text { findings can be further enhanced by } \\
\text { academic literature. At the moment, it is } \\
\text { supported by } 2 \text { literatures only }\end{array}$ & $\begin{array}{l}\text { This has been fully addressed. The results } \\
\text { have been expanded based on the nature of } \\
\text { practice and years of professional experience } \\
\text { of the respondents [refer to the section on } \\
\text { research findings for details] } \\
\text { Also the discussion section has been expand } \\
\text { and with support from academic literature. }\end{array}$ \\
\hline $\begin{array}{l}\text { 5. The discussion on the implications of } \\
\text { this research is quite limited. Further } \\
\text { discussion can be beneficial }\end{array}$ & $\begin{array}{l}\text { This has been addressed. Refer to the } \\
\text { section discussion of findings and } \\
\text { conclusions. }\end{array}$ \\
\hline $\begin{array}{l}\text { 6. Quality of communication is mostly } \\
\text { good. The paper is well-written. The } \\
\text { presentation of table can be improved. } \\
\text { For example, it may not be necessary to } \\
\text { put Table } 3 \text { as a separate table. }\end{array}$ & $\begin{array}{l}\text { The presentation has been improved. Tables } \\
3 \text { and } 4 \text { have been merged. It is now Table } 7 .\end{array}$ \\
\hline \multicolumn{2}{|c|}{ Reviewer 2} \\
\hline $\begin{array}{l}\text { 2. Relationship to Literature: }</ b>\text { Does the } \\
\text { paper demonstrate an adequate } \\
\text { understanding of the relevant literature in } \\
\text { the field and cite an appropriate range of } \\
\text { literature sources? Is any significant work }\end{array}$ & $\begin{array}{l}\text { Additional studies have been cited [Refer } \\
\text { section on Property Market Data Sources and } \\
\text { Challenges in Ghana] }\end{array}$ \\
\hline
\end{tabular}


Formatted: Font: $10 \mathrm{pt}$

Formatted: Font: $10 \mathrm{pt}$ $<\mathrm{b}>4$. Results: $</ \mathrm{b}>$ Are results presented clearly and analysed appropriately? Do the conclusions adequately tie together the other elements of the paper?:_The results are rather vague. There are many references to findings of a 'lack of reliable property market data'. Much more detail is needed on the issues and perceived problems.

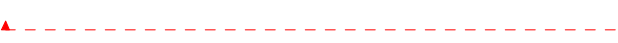
Idea of standard template and a databank are, I would suggest, fairly obvious. Contents of template suggested- where did they come from? If that was part of the discussion should be said so - can't believe that this amount of detail came from it. It does seem to assume that everyone would fill these in, honestly and completely - surely one of the issues around transaction information is unwillingness to reveal details? Who would run the databank?
The relevant literature was examined and based on that the indicators for the ideal or quality property market data were established to help drive the subsequent stages of the research. The literature review section (Property Market Data Sources and Challenges in Ghana).

The reasons why the stakeholder workshop was run have been made clearer at the methodology section. This makes clearer as why both the workshop and the questionnaire survey were undertaken. To reiterate, the workshop among others was to complement the literature review to collect qualitative such as data sources, possible information fields for property market data collection template whilst the questionnaire survey was used to collect information to measure the extent of usage, relevance etc.

The point of "lack of reliable market data" has been adequately explained. The literature discussions outlined what reliable/quality property market data is or should be. Based on that the situation in Ghana is examined. Issues such as incompleteness of data, data sources and integrity were highlighted in both the literature discussions and the discussion of findings sections. Besides, the study did not focus on determining whether there was a lack of reliable market data. Rather, given the fact that the lack of a reliable data has been established in the literature, the study was designed to find out the views of professional valuers on the sources of data they use and the extent of reliability of these sources. .

Also, the reviewer's suggestion that the idea 


\begin{tabular}{|l|l|}
\hline $\begin{array}{l}\text { of standard template and a databank is } \\
\text { obvious is well noted. However, what the } \\
\text { study sought to find out was the perception } \\
\text { of practitioners on the usefulness of such a } \\
\text { template and its content. }\end{array}$ \\
The contents of the template were obtained \\
from the literature and the discussions at the \\
stakeholder workshop. This has been made \\
clear in (the section on Indicators for Reliable \\
and Quality Data; the first paragraph of the \\
section on Research Methodology and the \\
last but paragraph on the section on \\
Outcome from the Stakeholder Workshop) \\
The participants at the stakeholder \\
workshop suggested that the GhIS should \\
take the initiative to build and run the \\
databank and this was reported as one of the \\
findings from the workshop.
\end{tabular}

